\title{
Facile Pd(II)- and $\mathrm{Ni(II)-Catalyzed} \mathrm{Isomerization} \mathrm{of} \mathrm{Terminal}$ Alkenes into 2-Alkenes
}

\author{
Hwan Jung Lim, Craig R. Smith, and T. V. RajanBabu* \\ Department of Chemistry, The Ohio State University, 100 W. $18^{\text {th }}$ Avenue, Columbus, Ohio 43210
}

\begin{abstract}
Mono- and 2,2'-di-substituted terminal alkenes can be isomerized into the more stable internal Zand $\mathrm{E}$ - alkenes by treating them with catalytic amounts of $[(\text { allyl }) \mathrm{PdCl}]_{2}$ or $[(\text { allyl }) \mathrm{NiBr}]_{2}$, a triarylphosphine and silver triflate at room temperature. The isomeric ratio $(E: Z)$ depends on the alkenes, the $(E)$-isomer being the major one. The reaction is tolerant to a wide variety of functional groups including other reactive olefins. Unlike the more reactive Ir catalysts, monosubstituted alkenes give almost exclusively the 2-alkenes. Direct comparison to two of the best-known catalysts for this process, $\left(\operatorname{Ir}\left(\mathrm{PCy}_{3}\right)_{3}\right]^{+}\left[\mathrm{BPh}_{4}\right]^{-}$, and Grubbs Generation II metathesis catalyst) is also reported.
\end{abstract}

\section{Introduction}

Isomerization of allylic derivatives is a well known reaction ${ }^{1}$ that has been used in unmasking allylic protecting groups, ${ }^{2}$ and enantioselective synthesis of vinyl amines ${ }^{3 \mathrm{a}}$ and ethers. ${ }^{3 \mathrm{~b}}$ Notable applications of the vinyl ether synthesis include the use of these intermediates for other $\mathrm{C}-\mathrm{C}$ bond-forming reactions such as Claisen rearrangements. ${ }^{4 a, b}$ The isomerization reaction has also been used for the stereoselective syntheses of silyl ethers of aldehyde enols. ${ }^{4 c, d}$ Depending on the metal and the reaction conditions, varying selectivities for the isomerized $E$ - and $Z$ - alkenes have been observed. In general, while Ni(II)-catalysts deliver the best Z:E ratios, ${ }^{5}$ Ir-catalysts are the optimal reagents for the preparation of $E$-olefins (Scheme 1) ${ }^{4 \mathrm{~b}-\mathrm{d} \text {, }}$ ${ }^{6}$ Low-yielding isomerizations of terminal alkenes catalyzed by $\mathrm{Pt}^{7 \mathrm{a}} \mathrm{Rh}^{7 \mathrm{a}} \mathrm{Pd}^{7 \mathrm{~b}}$ and $\mathrm{Ni}^{7 \mathrm{c}}$ have been known since 1964. The role of a bulky ligand and the intermediacy of the metal hydride implied in the $\left.\left[2-\mathrm{Me}_{-} \mathrm{C}_{6} \mathrm{H}_{4}-\mathrm{O}\right)_{3} \mathrm{P}\right]_{3} \mathrm{Ni} / \mathrm{HCl}^{7 \mathrm{c}}$ have been effectively used to design other protocols for this reaction. ${ }^{7 \mathrm{~d}, \mathrm{e}}$ Iridium (I) catalysts originally developed by Felkin ${ }^{6 \mathrm{a}}$ have been modified for the skeletal isomerization of functionalized terminal alkenes at room temperature. 6a-e The most recent entry into this group of catalysts capable of effecting the skeletal isomerization of $C$-allylic appendages in highly functionalized substrates is the Grubbs generation II metathesis catalyst that has been 'thermally modified' (eq 1). ${ }^{8}$

E-mail: rajanbabu.1@osu.edu.

SUPPORTING INFORMATION. Spectroscopic data $\left({ }^{1} \mathrm{H}\right.$ and ${ }^{13} \mathrm{C}$ NMR), gas chromatographic traces of starting materials, products and of crude isomerization products. This material is available free of charge via the Internet at http://pubs.acs.org. 


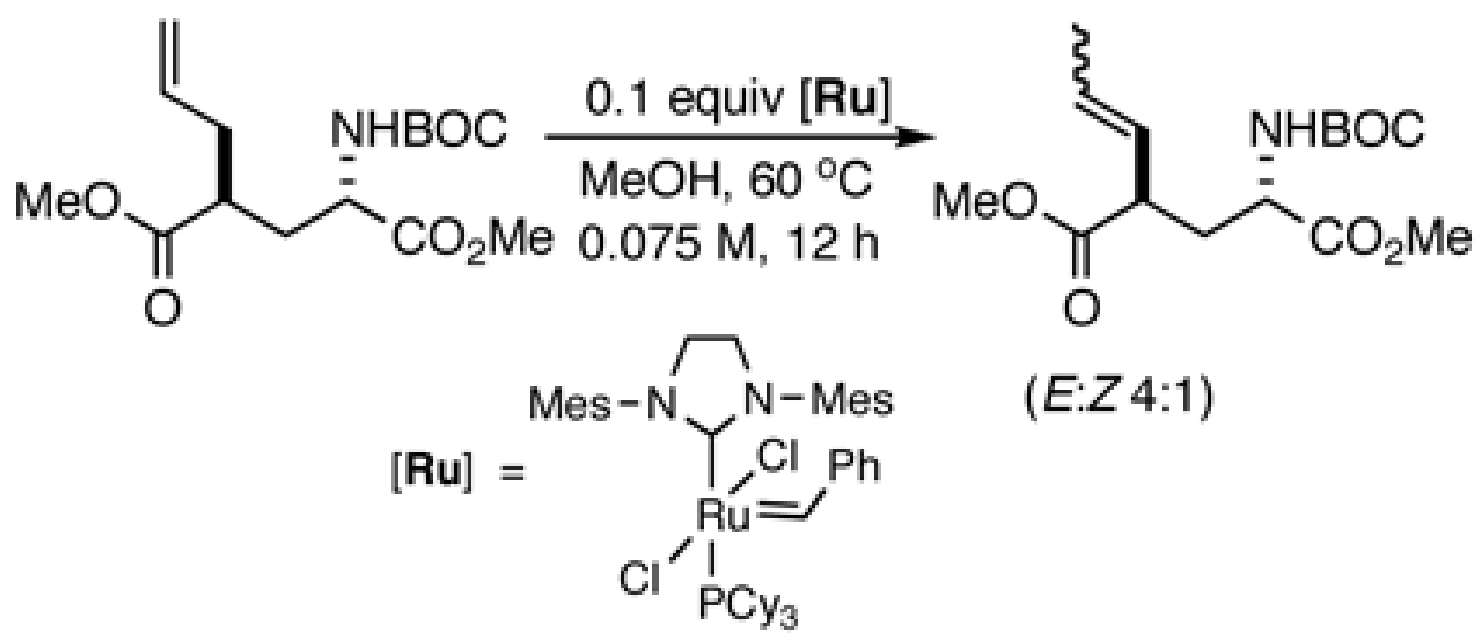

(1)

During our studies on asymmetric hydrovinylation of 2,2'-disubstituted alkenes we noticed that some substrates consistently gave varying proportions of a minor component readily identified as the allylic rearrangement product as illustrated in eqs $2 \mathrm{a}$ and $2 \mathrm{~b} \cdot{ }^{9} \mathrm{~A}$ similar rearrangement was also detected during cycloisomerization of dienes catalyzed by $\{[($ allyl) $\left.\mathrm{PdCl}]_{2} / \mathrm{AgOTf} /\left[\left(2-\mathrm{Me}-\mathrm{C}_{6} \mathrm{H}_{4}\right)_{3} \mathrm{P}\right]\right\}$ (eq 3). ${ }^{10}$
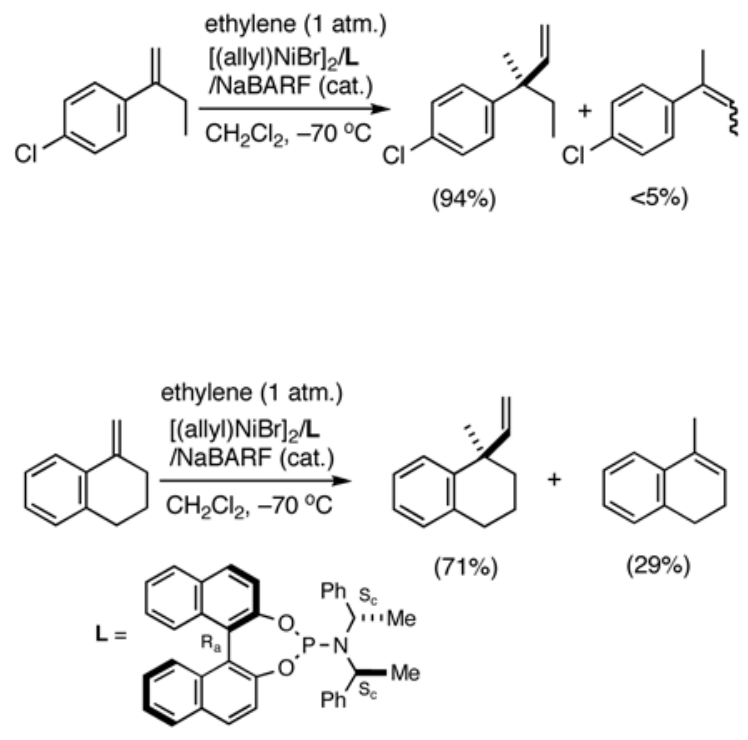


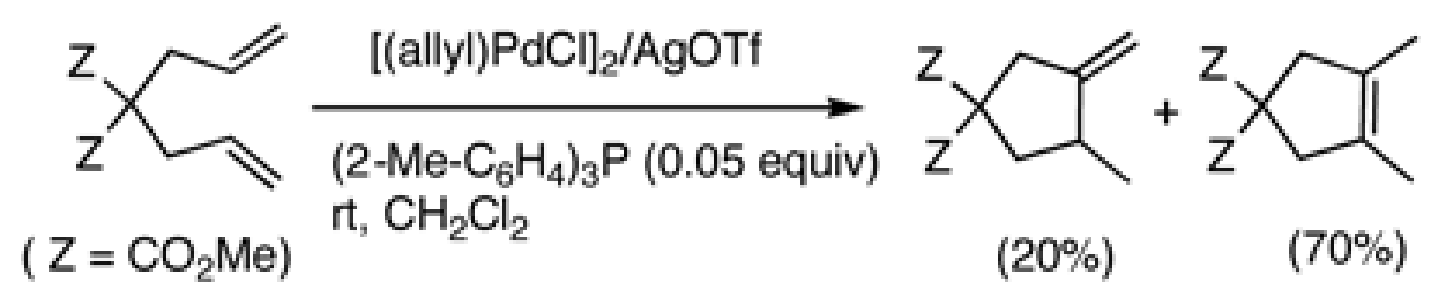

Since cationic metal hydrides have been implicated in these reactions, we wondered whether the hydrovinylation conditions could be modified to improve the yield of selective isomerization of a monosubstituted terminal alkene into a 2-alkene and of a 2,2'-disubstituted alkene into a trisubstituted alkene. We are especially interested in avoiding the complication from subsequent isomerization of the primary product, which often accompanies some of the isomerization reactions of terminal alkenes involving $\mathrm{Ir}^{6 \mathrm{~b}, \mathrm{e}}$ and $\mathrm{Ru} .{ }^{8 \mathrm{~h}}$ This isomerization is especially problematic when the homoallylic position of the carbon chain in the starting alkene is unsubstituted (eq 4). There are only limited reports of rearrangements of 2,2'-disubstituted alkenes to the corresponding internal trisubstituted isomer. ${ }^{8 \mathrm{~h}}$ When coupled with a Wittig, Grignard or Keck radical allylation ${ }^{8 \mathrm{f}}$ reaction, to produce the ethylidene derivative, this transformation could be quite useful. In acyclic systems, the configuration of the newly formed carbon-carbon double bond would also be of some interest. ${ }^{11}$ The results of these studies are reported here.
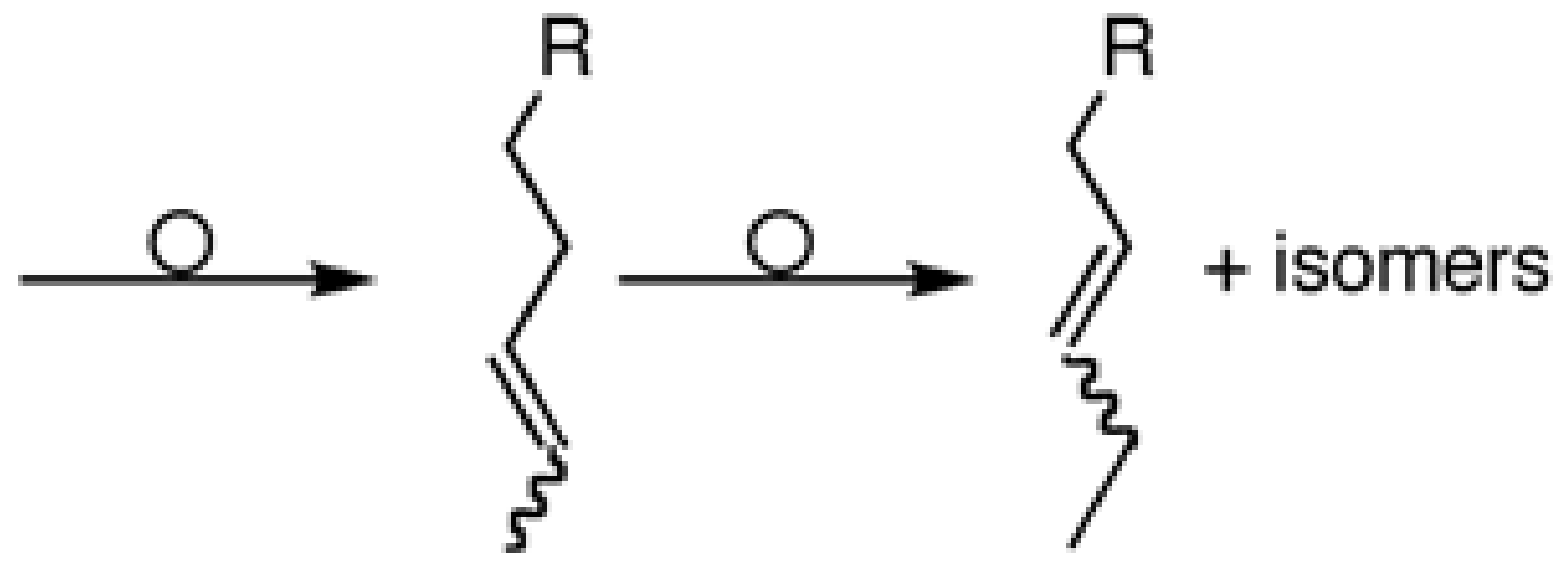

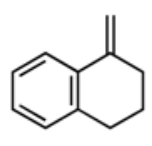

1

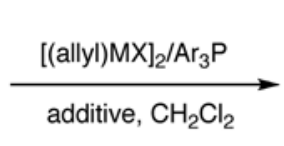

(90-99\%)

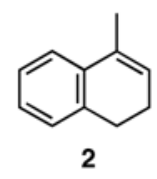

$\mathrm{M}=\mathrm{Ni}, \mathrm{Pd}$ additive; AgOTf, NaBARF 


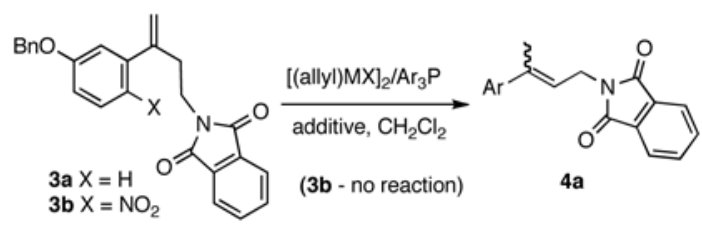

\section{Results}

Our initial studies concentrated on the little known ${ }^{8 \mathrm{~h}}$ isomerization of the $2,2^{\prime}$-disubstituted alkenes. Results of isomerization of two prototypical substrates 1-methylenetetralin (1, eq 5) and the 1-(2-phthalimidoethyl)styrene (3a' eq 6) are shown in Table 1. When $\mathbf{1}$ was reacted under typical hydrovinylation conditions ${ }^{12}$ using $\mathrm{Ph}_{3} \mathrm{P}$ as a ligand, $\left\{[(\text { allyl }) \mathrm{NiBr}]_{2}, \mathrm{Ph}_{3} \mathrm{P}\right.$, AgOTf, $\left.\left.25^{\circ} \mathrm{C}, 2 \mathrm{~d}\right)\right\}$ in an atmosphere of ethylene, no reaction ensued (entry 1, column 4). In accordance with our previous observation that $\mathrm{Pd}$ (II) salts show enhanced reactivity under these conditions, ${ }^{12 \mathrm{~b}}$ the use of $[(\text { allyl }) \mathrm{PdCl}]_{2}$ instead of the corresponding Ni salt leads to the expected product 2 in very good yield (entry 2 , column 4 ). ${ }^{13}$ Typically the reaction involving ethylene is carried out as follows: appropriate amounts of the metal salt, the phosphine and AgOTf are mixed in $\mathrm{CH}_{2} \mathrm{Cl}_{2}$ in a drybox in a Schlenk tube, the mixture is taken out of the box and placed in an atmosphere of ethylene for $20 \mathrm{~min}$. The alkene is introduced and the ethylene atmosphere is replaced by nitrogen, and the mixture is stirred for 2 days at rt. Unlike the hydrovinylation reaction, there is no need to remove the precipitated salts $(\mathrm{AgX})$ for the isomerization reactions. While the use of ethylene has a slight advantage in the recovery of products, we find that an operationally simpler procedure is to use catalytic amounts of diallyl ether (entry 3). Presumably diallyl ether, which undergoes facile cycloisomerization to 3methylene-4-methyltetrahydrofuran, readily produces ${ }^{10 a, b}$ the requisite cationic metal hydride with minimum of contamination by other side products. Use of diallyl ether also helps the $\mathrm{Ni}$ catalyzed reaction if a highly dissociated counter-anion, $\left[\left(3,5-\left(\mathrm{CF}_{3}\right)_{2} \mathrm{C}_{6} \mathrm{H}_{3}\right]_{4} \mathrm{~B}^{-}\right.$, is used instead of OTf (entry 4 , column 4). ${ }^{14,12 \mathrm{~b}}$ Thus with $1 \mathrm{~mol} \%$ of $\left[(\operatorname{allyl})_{2} \mathrm{NiBr}\right]_{2}$, and $2 \mathrm{~mol} \%$ each of $\mathrm{Ph}_{3} \mathrm{P}, \mathrm{Na}^{+}\left[\left(3,5-\left(\mathrm{CF}_{3}\right)_{2} \mathrm{C}_{6} \mathrm{H}_{3}\right]_{4} \mathrm{~B}^{-}\right.$(BARF) and diallyl ether 1 gives very good yield of the isomerization product 2 (entry 4 ).

Isomerization of functionalized alkene 3a (eq 6) is best carried out in the presence of ethylene or diallyl ether (entries 2 and 3, column 5) since other conditions gave virtually no reaction. The ratio of $E: Z$ alkenes was found to depend on the additive, with ethylene giving the mixture in an $E: Z$ ratio of $15: 1$ as determined by ${ }^{1} \mathrm{H}$ NMR. This reaction appears to be very sensitive to steric effects, since the $o$-substituted derivative $\mathbf{3 b}$ gave no product.

Experimentally the use of commercially available $[(\text { allyl }) \mathrm{PdCl}]_{2}$ has a clear advantage over $[(\text { allyl }) \mathrm{NiBr}]_{2}$, which is a thermally sensitive solid that has to be kept at low temperature in a drybox. ${ }^{15}$ In subsequent experiments we discovered that for simple substrates such as $\mathbf{1}$ when the Pd-catalyzed reaction is carried out in the presence of $(o \text {-tolyl })_{3}$ phosphine, there is no need to have the ethylene or diallyl ether present for a quantitative conversion to the product (entry 5, column 4).

Entries $6^{6 \mathrm{~d}}$ and $7^{8 \mathrm{a}}$ lists the use of two of the best catalysts capable of allylic isomerizations. Neither the Ir (I) nor the modified Grubbs generation II catalyst under the prescribed reaction conditions is useful for this transformation.

Further scope of the reaction is shown in Table 2, which lists other alkenes that undergo the isomerization under these conditions. The 1-indanone-derived alkene 5 gave an excellent yield 
of the internal alkene at room temperature (entry 1). Methylene compounds prepared via Wittig reaction of aryl alkyl ketones are excellent substrates for this reaction. 2-Arylbutenes 6-8 gave excellent yields of the product, an internal alkene. While the 2-naphthyl derivative 7 gave good $E$-selectivity, the 1-naphthyl analog 8 gave only a 2:1 mixture of $E$ and $\mathrm{Z}$ alkenes. Attempted isomerization of the furyl derivative $\mathbf{9}$ led to polymerization.

Monosubstituted terminal alkenes also undergo the isomerization with remarkable ease under the typical conditions outlined in the previous paragraph giving exclusively the 2-alkene.

Several non-trivial examples of this transformation are shown in Table 3. 6-(tert-

Butyldimethylsiloxy)hex-1-ene 13 undergoes exceptionally clean isomerization to the corresponding $Z$ - and $E$-2-hexenes (18) under typical hydrovinylation conditions at $-55{ }^{\circ} \mathrm{C}$ (entry 1). ${ }^{13}$ The expected internal olefin $\mathbf{1 8}$ is formed in $>95 \%$ yield in an $E: Z$ ratio of 3.5:1.0 as judged by ${ }^{1} \mathrm{H}$ NMR spectroscopy and gas chromatography. No trace of any other alkenes is observed under these conditions. The reaction catalyzed by $\mathrm{Pd}(\mathrm{II})$ (entry 2 ) gives $80 \%$ yield of $(E)$ - and $(Z)-\mathbf{1 8}$ in the same ratio. This reaction is less clean compared to the Ni-catalyzed reaction, the product being contaminated with up to $10 \%$ starting material, and $9 \%$ of another isomeric alkene. ${ }^{13}$ Isomerization of $\mathbf{1 3}$ using the metathesis catalyst (eq 1, 10 mol \% [Ru], $\mathrm{MeOH}, 60{ }^{\circ} \mathrm{C}, 12 \mathrm{~h}$ ) yields $<45 \%$ of the $E / Z$ mixture (3.8:1.0) of $\mathbf{1 8}$ contaminated with other isomers. The $\operatorname{Ir}(\mathrm{I})$ catalyst $\left[(\mathrm{Ir}(\mathrm{COE}) \mathrm{Cl}]_{2}, \mathrm{PCy}_{3}, \mathrm{NaBPh}_{4}, \mathrm{CH}_{2} \mathrm{Cl}_{2} / \text { acetone (50:1) }\right]^{4 \mathrm{~b}}$ gave $94 \%$ yield of (E)-1-t-butyldimethylsiloxyhexene (Scheme 2).

The proportion of starting material in the equilibrium mixture of alkenes depends on the starting alkene, as indicated by the isomerization in 1-(but-3-enyloxy)-4-methoxybenzene (14) to the disubstituted alkene 19. The $E$ - and $Z$ - isomers are obtained in $>95 \%$ yield in a ratio of 5.9:1.0 with $<4 \%$ of the starting material (entry 3 ). The $\operatorname{Ir}(\mathrm{I})$-catalyst gives a mixture of products arising from both 1,3- and 1,6-hydrogen shifts with the latter predominating (Scheme 2). ${ }^{13}$ The modified Grubbs catalyst gave a mixture of 14\% starting material, 47\% (E)-19,12\% (Z)-19 along with a mixture of isomers. ${ }^{13}$ While 1,6 -dienes readily undergo cycloisomerization followed by isomerization of the exocyclic alkylidene under Pd-catalysis (eq 3), ${ }^{10 a}$ a substrate more resistant to cyclization, such as 1,7-octadiene (15), simply undergoes isomerization of the terminal alkenes to give a stereoisomeric mixture of 2,6- octadienes (20) [entry 4].

Surprisingly, the triene 16, prone to isomerization of the endocyclic 1,4-diene, cleanly gives $90 \%$ yield of a mixture of $E$ - and Z-3-butenyl derivatives (21) arising from selective isomerization of the side-chain (entry 5). Likewise, the enyne 17 undergoes just the isomerization to 22 without the expected 16 cyclization of the enyne to a bisalkylidene.

Finally, several sterically demanding substrates, 23-26, failed to undergo isomerization even under more forcing conditions.

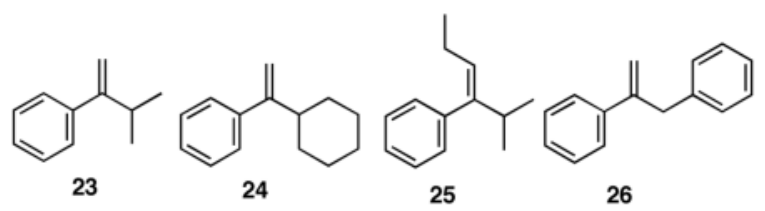

\section{Discussion}

Mechanistically the alkene isomerization is related to the olefin dimerization reaction since both start with a common reactive intermediate in the form of an active metal hydride. Such a hydride (32, Scheme 3) could be generated by initial formation of the [(allyl)metal (phopshine) $]^{+}$OTf $^{-}(\mathbf{2 8})^{14}$ from the metal halide followed by an insertion (29 $\left.\rightarrow \mathbf{3 0}\right)$ and $\beta$ hydride elimination. The 1,4-diene $\mathbf{3 1}$ is formed as a byproduct. ${ }^{10 b, 17}$ Once the hydride is generated it adds to the terminal alkene to form a organometallic $\mathbf{3 3}$, which undergoes yet 
another $\beta$-hydride elimination to give the alkene isomers (34) in a thermodynamically controlled reaction. Note that almost invariably, the $E$-alkenes predominate in the isomerization reactions. The reluctance of the 1,1'-disubstituted alkene to undergo the reaction in the absence of a sterically unencumbered alkene, ethylene, is thus easily understood. A 1,1'-disubstututed alkene $\left(\mathrm{R}^{\prime}=\right.$ alkyl) could be slow to undergo the allylic insertion reaction $(\mathbf{2 9} \rightarrow \mathbf{3 0})$ and ethylene is needed to generate the reactive metal hydride. The reluctance of the metal hydride to add to a 1,2-disubstituted alkene $\left(\mathbf{3 4}, \mathrm{R}^{\prime}=\mathrm{H}\right)$ might also explain why the exhaustive isomerizations seen with other catalysts (Scheme 2), most notably $\operatorname{Ir}(\mathrm{I})$, is not seen in these reactions.

\section{Conclusions}

The cationic metal hydride-mediated selective skeletal isomerization of terminal alkenes provides a facile route to di- and trisubstituted alkenes. The reaction is sensitive to steric effects, yet tolerant to a variety of common functional groups and, in some cases, may provide synthetically useful levels of $E: Z$ selectivity in the formation of the trisubstituted alkenes.

\section{Experimental Section}

\section{General Information}

See Supporting Information.

\section{Attempted isomerization of 1-methylene-2,3,4-trihydronaphthalene 1 under hydrovinylation conditions. General procedure A (Table 1, entry 1, column 4)}

In a flame-dried flask, $[(\text { allyl }) \mathrm{NiBr}]_{2}$ or $[(\text { allyl }) \mathrm{PdCl}]_{2}$, the phosphine ligand and the silver salt were mixed in that order in $\mathrm{CH}_{2} \mathrm{Cl}_{2}$ in a drybox. After the precipitated silver salt was removed by filtration though celite, the solution was taken out of the drybox and was connected to an ethylene line. The system was evacuated and refilled with ethylene three times. To the resulting complex was added 1 in $\mathrm{CH}_{2} \mathrm{Cl}_{2}$ dropwise at room temperature. After stirring for the prescribed time (Table 1), all volatile materials were removed and the product was purified by column chromatography. Gas chromatography and NMR showed complete recovery of starting materials. We have since found that for most isomerization reactions described below it is not necessary to remove the precipitated silver salt.

Use of [(allyl)PdCl $]_{2} /$ phosphine/AgOTf activated by ethylene for the double bond migration. General procedure B (Table 1, entry 2, columns 4 and 5 )

In a flame dried three-neck flask, [(allyl)PdCl $]_{2}, \mathrm{PPh}_{3}$ and $\mathrm{AgOTf}$ were dissolved in $\mathrm{CH}_{2} \mathrm{Cl}_{2}$ in a glove box. After the reaction vessel was taken out of the box, an ethylene line was connected to the vessel and the line was evacuated, then ethylene was introduced. The process was repeated three times. The resulting monomeric allylic Pd complex was stirred for 20 min under one atmosphere of ethylene at rt. Then the exo-methylene substrate $\mathbf{1}$ or $\mathbf{3 a}$ was added dropwise as a solution in $\mathrm{CH}_{2} \mathrm{Cl}_{2}$. The ethylene was exchanged with a $\mathrm{N}_{2}$ atmosphere and the resulting mixture was stirred at ambient temperature for the prescribed time. All volatile materials were evaporated, and then the mixture was filtered using a short pad of silica gel using EtOAc/Hex solvent. The product was analyzed by GC and NMR.

\section{Use of $\left[(\text { allyl)PdCl }]_{2} /\right.$ phosphine/AgOTf activated by diallyl ether for the double bond migration. General procedure $C$ (Table 1, entry 3, columns 4 and 5 )}

To a premixed allyl-Pd complex in $\mathrm{CH}_{2} \mathrm{Cl}_{2}$ which was prepared in the same fashion as in the previous experiment (General Procedure B), an equivalent amount of diallylether was added instead of ethylene and then the mixture was stirred at $\mathrm{rt}$ for $20 \mathrm{~min}$. The substrate dissolved in $\mathrm{CH}_{2} \mathrm{Cl}_{2}$ was added dropwise to the catalyst solution, and the resulting mixture was stirred 
at ambient temperature for the indicated time. The product was purified and analyzed as indicated previously.

Use of [(allyl)PdCl $]_{2} /$ phosphine/AgOTf without any additive for the double bond migration. General procedure $D$ (Table 1, entry 5, columns 4 and 5 )

To (allyl)Pd(phosphine)-complex in $\mathrm{CH}_{2} \mathrm{Cl}_{2}$ which was prepared in the same fashion as in the General Procedure B, the substrate dissolved in $\mathrm{CH}_{2} \mathrm{Cl}_{2}$ was added dropwise, and the resulting mixture was stirred at ambient temperature for the indicated time. The product was purified and analyzed as indicated previously.

\section{Isomerization of 1 using [(allyl)NiBr $]_{2} / \mathrm{Ph}_{3} \mathrm{P} / \mathrm{NaBARF}$ and diallylether. (Table 1 , entry 4 , column 4)}

The pre-catalyst was prepared as follows in a glovebox: To [(allyl)NiBr $]_{2}(10.8 \mathrm{mg}, 0.03 \mathrm{mmol})$ in $\mathrm{CH}_{2} \mathrm{Cl}_{2}(1 \mathrm{~mL})$ were added $\mathrm{PPh}_{3}(15.7 \mathrm{mg}, 0.06 \mathrm{mmol})$ and $\mathrm{NaBARF}(53.0 \mathrm{mg}, 0.06 \mathrm{mmol})$. The catalyst solution prepared above was removed from the drybox, and diallylether $(3.7 \mu \mathrm{L}$, $0.03 \mathrm{mmol}$ ) was added as a single portion under nitrogen and the mixture was allowed to stir for $2 \mathrm{~min}$ to form the active catalytic species. A solution of the substrate $1(433 \mathrm{mg}, 3.00 \mathrm{mmol}$ ) in $3 \mathrm{~mL}$ of $\mathrm{CH}_{2} \mathrm{Cl}_{2}$ was added dropwise over a period of one minute and the reaction was allowed to proceed for $2 \mathrm{~d}$. The resulting product was filtered by flash column chromatography (eluted with pentane) to get the desired product $2(0.35 \mathrm{~g}, 82 \%)$ as a colorless oil, which was then used to acquire all analytical data without further purification. ${ }^{1} \mathrm{H} \mathrm{NMR}\left(\mathrm{CDCl}_{3}\right): \delta$ 7.23-7.17 (m, $2 \mathrm{H}$ ), 7.15-7.10 (m, $2 \mathrm{H}), 5.85-5.83(\mathrm{~m}, 1 \mathrm{H}), 2.75(\mathrm{t}, J=8.0 \mathrm{~Hz}, 2 \mathrm{H}), 2.26-2.20$ $(\mathrm{m}, 2 \mathrm{H}), 2.04(\mathrm{dd}, J=3.2 \mathrm{~Hz}, J=1.6 \mathrm{~Hz}, 3 \mathrm{H}) ;{ }^{13} \mathrm{C} \mathrm{NMR}\left(\mathrm{CDCl}_{3}\right): \delta 136.3,135.9,132.3$, $127.3,126.7,126.3,125.4,122.8,28.3,23.2,19.3$.

\section{Isomerization of 2-(3-(3-(benzyloxy)phenyl)but-3-enyl)isoindoline-1,3-dione, 3a (Table 1, entry 2, column 5). General procedure B}

In a flame dried three-neck flask, [(allyl)PdCl $]_{2}(2.4 \mathrm{mg}, 0.0061 \mathrm{mmol}), \mathrm{PPh}_{3}(3.7 \mathrm{mg}, 0.013$ mmol) and AgOTf ( $3.4 \mathrm{mg}, 0.013 \mathrm{mmol}$ ) were dissolved in distilled $\mathrm{CH}_{2} \mathrm{Cl}_{2}(3 \mathrm{~mL})$ in a glove box. After the reaction vessel was taken out from a box, an ethylene line was connected to the vessel and the line was evacuated, and then ethylene was introduced. This process was repeated three times. The resulting Pd complex was stirred for 20 min under $1 \mathrm{~atm}$ of ethylene atmosphere at rt, and then the exomethylene substrate $3 \mathbf{a}(29 \mathrm{mg}, 0.076 \mathrm{mmol})$ in $\mathrm{CH}_{2} \mathrm{Cl}_{2}$ (1 $\mathrm{mL}$ ) was added dropwise. Ethylene atmosphere was exchanged for a $\mathrm{N}_{2}$ atmosphere, the resulting mixture was stirred at $35^{\circ} \mathrm{C}$ for $2 \mathrm{~d}$. All volatile materials were evaporated, and then the mixture was purified by flash column chromatography to get $28 \mathrm{mg}(79 \%)$ of the product 4a $(\mathrm{E}: \mathrm{Z}=15: 1)$ contaminated with $21 \%$ of starting olefin, 3a. ${ }^{1} \mathrm{H}$ NMR $\left(\mathrm{CDCl}_{3}\right): \delta 7.90-7.69$ (m, $4 \mathrm{H}$, phthalimidyl), 7.49-7.29 (m, $5 \mathrm{H}, \mathrm{Ar}), 7,19$ (t, $J=6.4 \mathrm{~Hz}, 1 \mathrm{H}, \mathrm{Ar}), 7.05-6.85$ (m, 2 $\mathrm{H}, \mathrm{Ar}), 6.84-6.79(\mathrm{~m}, 1 \mathrm{H}, \mathrm{Ar}), 5.85$ (t, $\left.J=7.0 \mathrm{~Hz}, 1 \mathrm{H}, \mathrm{Ar}\left(\mathrm{CH}_{3}\right) \mathrm{C}=\mathrm{CHCH}_{2} \mathrm{~N}-\mathrm{phth}\right), 5.03$ (s, $\left.2 \mathrm{H}, \mathrm{OCH}_{2} \mathrm{Ph}\right), 4.50\left(\mathrm{~d}, 7.5 \mathrm{~Hz}, 2 \mathrm{H}, \mathrm{Ar}\left(\mathrm{CH}_{3}\right) \mathrm{C}=\mathrm{CHCH}_{2} \mathrm{~N}\right.$-phth, E), $4.22(\mathrm{~d}, \mathrm{~J}=6.5 \mathrm{~Hz}, 2 \mathrm{H}$, $\mathrm{Ar}\left(\mathrm{CH}_{3}\right) \mathrm{C}=\mathrm{CHCH}_{2} \mathrm{~N}$-phth, $\left.\mathrm{Z}\right), 2.23\left(\mathrm{~s}, 3 \mathrm{H}, \mathrm{Ar}\left(\mathrm{CH}_{3}\right) \mathrm{C}=\mathrm{CHCH}_{2} \mathrm{NPhth}, \mathrm{E}\right), 2.01(\mathrm{~s}, 3 \mathrm{H}, \mathrm{Ar}$ $\left(\mathrm{CH}_{3}\right) \mathrm{C}=\mathrm{CHCH}_{2} \mathrm{~N}-$ phth, $\left.\mathrm{Z}\right)$. 


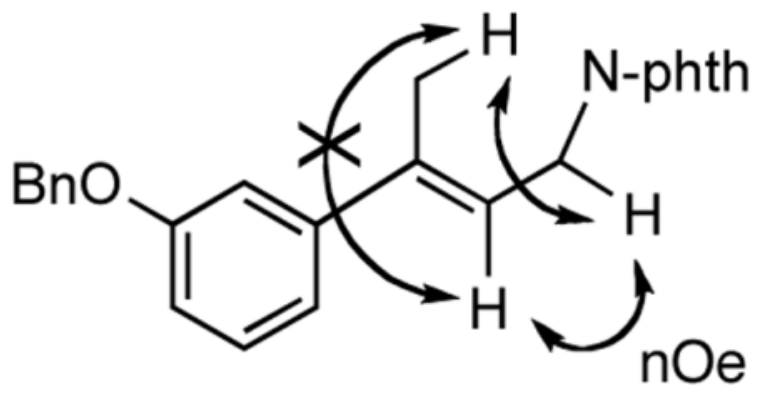

The configuration of the major product was established by nOe studies. ${ }^{13} \mathrm{C} \mathrm{NMR}\left(\mathrm{CDCl}_{3}\right)$ : $\delta$ 168.4, 144.5, 139.4, 137.3, 134.1, 132.5, 129.6, 128.1, 127.8, 123.4, 121.6, 119.1, 113.7, 113.1, 70.2, 36.5, 16.4. HRMS $406.1400\left(\mathrm{M}+\mathrm{Na}^{+\bullet}\right.$; calcd for $\left.\mathrm{C}_{25} \mathrm{H}_{21} \mathrm{NNaO}_{3} 406.1419\right)$

Isomerization of 1-methylene-1,2,3,-trihydronaphthalene, 1 (Table 1, entry 2, column 4). General procedure D

Following the general procedure D using $10 \mathrm{~mol} \%$ of preformed Pd-catalyst, the isomerization of $1(0.145 \mathrm{~g}, 1.0 \mathrm{mmol})$ was checked. After the crude product was purified by column chromatography, the product $(\mathbf{2}, 0.145 \mathrm{~g},>99 \%)$ was analyzed by NMR.

\section{Isomerization of 1-methylene-2,3-dihydro-1H-indene 5 (Table 2, entry 1). General procedure} D

The isomerization reaction of $5(0.131 \mathrm{~g}, 1.0 \mathrm{mmol})$ was carried out using [(allyl) $\mathrm{PdCl}]_{2}(5$ mol\%), (o-tol) ${ }_{3} \mathrm{P}(10 \mathrm{~mol} \%)$ and $\mathrm{AgOTf}(10 \mathrm{~mol} \%)$ in $\mathrm{CH}_{2} \mathrm{Cl}_{2}$ with no other additive at rt for $8 \mathrm{~h}$. After the solvent was evaporated, the crude product was purified by column chromatography to yield the desired product 9 (94\%, isolated yield). ${ }^{1} \mathrm{H} \mathrm{NMR}\left(\mathrm{CDCl}_{3}\right): \delta 7.47$ (d, $1 \mathrm{H}, J=7.2 \mathrm{~Hz}, \mathrm{Ar}), 7.39-7.31$ (m, 2H, Ar), 7.27- 7.23 (m, 1H, Ar), 6.22 (s, 1H, vinyl), 3.33 (s, $2 \mathrm{H}$, allylic $\left.\mathrm{CH}_{2}\right), 2.19$ (s, $3 \mathrm{H}$, allylic $\left.\mathrm{CH}_{3}\right) ;{ }^{13} \mathrm{C} \mathrm{NMR}\left(\mathrm{CDCl}_{3}\right): \delta 146.1,144.3,139.9,128.7$, $126.0,124.4,123.6,118.8,37.6,13.0$.

\section{Isomerization of 1-(but-1-en-2-yl)-4-chlorobenzene 6 (Table 2, entry 2). General procedure D}

The isomerization reaction of $6(0.167 \mathrm{~g}, 1.0 \mathrm{mmol})$ was carried out using [(allyl) $\mathrm{PdCl}]_{2}(5$ mol\%), $(o \text {-tol })_{3} \mathrm{P}(10 \mathrm{~mol} \%)$ and AgOTf $(10 \mathrm{~mol} \%)$ in $\mathrm{CH}_{2} \mathrm{Cl}_{2}$ with no other additive at $\mathrm{rt}$ for $16 \mathrm{~h}$. After the solvent was evaporated, the crude product was purified by column chromatography to yield the desired product $10(87 \%, E: Z=19: 1) .{ }^{1} \mathrm{H} \mathrm{NMR}\left(\mathrm{CDCl}_{3}\right): \delta$ 7.33-7.27 (m, 4H, Ar), $5.86\left(\mathrm{q}, 1 \mathrm{H}, J=6.50 \mathrm{~Hz}\right.$, vinyl), $2.02\left(\mathrm{~s}, 3 \mathrm{H}\right.$, allylic $\left.\mathrm{CH}_{3}\right), 1.80(\mathrm{~d}, 3 \mathrm{H}$,

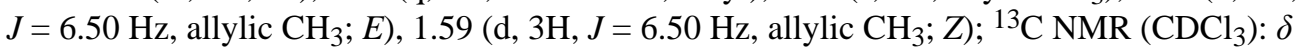
$142.4,134.5,132.1,128.2,126.8,123.0,15.4,14.3$.

\section{Isomerization of 2-(but-1-en-2-yl)naphthalene 7 (Table 2, entry 3). General procedure D}

The isomerization reaction of $7(0.182 \mathrm{~g}, 1.0 \mathrm{mmol})$ was carried out using [(allyl) $\mathrm{PdCl}]_{2}(5$ mol\%), (o-tol) $)_{3} \mathrm{P}(10 \mathrm{~mol} \%)$ and $\mathrm{AgOTf}(10 \mathrm{~mol} \%)$ in $\mathrm{CH}_{2} \mathrm{Cl}_{2}$ with no other additive at $\mathrm{rt}$ for $16 \mathrm{~h}$. After the solvent was evaporated, the crude product was purified by column chromatography to yield the desired product $11(97 \%, E: Z=9: 1) .{ }^{1} \mathrm{H}$ NMR $\left(\mathrm{CDCl}_{3}\right): \delta$ 7.83-7.81 (m, 2H, Ar), 7.79-7.76 (m, 2H, Ar), 7.58 (dd, 1H, $J=9.0,2.0 \mathrm{~Hz}, \mathrm{Ar}), 7.47-7.42$ (m, $2 \mathrm{H}, \mathrm{Ar}), 6.05$ (q, $1 \mathrm{H}, J=7.0 \mathrm{~Hz}$, vinyl; $E$ ), 2.15 (s, $3 \mathrm{H}$, allylic $\left.\mathrm{CH}_{3} ; E\right), 2.13$ (s, 3H, allylic $\left.\mathrm{CH}_{3} ; Z\right), 1.87$ (d, $3 \mathrm{H}, J=7.0 \mathrm{~Hz}$, allylic $\left.\mathrm{CH}_{3} ; E\right), 1.67\left(\mathrm{~d}, 3 \mathrm{H}, J=7.0 \mathrm{~Hz}\right.$, allylic $\mathrm{CH}_{3}$; $Z) ;{ }^{13} \mathrm{C} \mathrm{NMR}\left(\mathrm{CDCl}_{3}\right): \delta 141.2,135.4,133.5,132.3,128.0,127.5,127.4,126.0,125.3,124.3$, $123.8,123.1,15.5,14.5$. 


\section{Isomerization of 1-(but-1-en-2-yl)naphthalene 8 (Table 2, entry 4). General procedure D}

The isomerization reaction of $\mathbf{8}(0.182 \mathrm{~g}, 1.0 \mathrm{mmol})$ was carried out using [(allyl) $\mathrm{PdCl}]_{2}(5$ mol\%), $(o \text {-tol })_{3} \mathrm{P}(10 \mathrm{~mol} \%)$ and $\mathrm{AgOTf}(10 \mathrm{~mol} \%)$ in $\mathrm{CH}_{2} \mathrm{Cl}_{2}$ at $\mathrm{rt}$ for $16 \mathrm{~h}$. After the solvent was evaporated, the crude product was purified by column chromatography to yield the desired product $12(99 \%, E: Z=2: 1) .{ }^{1} \mathrm{H}$ NMR $\left(\mathrm{CDCl}_{3}\right): \delta 8.03(\mathrm{dd}, 1 \mathrm{H}, J=6.0,2.5 \mathrm{~Hz}, \mathrm{Ar}), 7.90$ (dd, $1 \mathrm{H}, J=8.0,3.5 \mathrm{~Hz}, \mathrm{Ar}), 7.79(\mathrm{~d}, 1 \mathrm{H}, J=8.0 \mathrm{~Hz}, \mathrm{Ar}), 7.54-7.50(\mathrm{~m}, 3 \mathrm{H}, \mathrm{Ar}), 7.32$ (d, $1 \mathrm{H}$, $J=6.5 \mathrm{~Hz}, \mathrm{Ar}), 5.87(\mathrm{q}, 1 \mathrm{H}, J=7.0 \mathrm{~Hz}$, vinyl; $Z), 5.66(\mathrm{q}, 1 \mathrm{H}, J=6.50 \mathrm{~Hz}, 1 \mathrm{H} ; E), 2.16(\mathrm{~s}$, $3 \mathrm{H}), 1.94(\mathrm{~d}, J=6.50 \mathrm{~Hz}, 3 \mathrm{H}), 1.42(\mathrm{~d}, J=6.50 \mathrm{~Hz} ; Z) ;{ }^{13} \mathrm{C} \mathrm{NMR}\left(\mathrm{CDCl}_{3}\right): \delta E-144.3,135.7$, $133.8,131.4,128.3,126.7,126.0,125.6,125.5,125.4,124.9,18.7,14.0 . Z-140.5,135.8$, $133.7,130.8,128.3,125.8,125.6,125.2,124.9,123.3,26.1,14.8$.

\section{Isomerization of 1,7-octadiene (Table 3, entry 4). General procedure D}

In a nitrogen filled drybox, a dry flask was charged with [(allyl)PdCl $]_{2}(0.016 \mathrm{~g}, 0.045 \mathrm{mmol})$ in $1 \mathrm{~mL} \mathrm{CH}_{2} \mathrm{Cl}_{2}$. To this solution was added two equivalents of phosphine ligand (one equiv with respect to metal, $0.024 \mathrm{~g}, 0.09 \mathrm{mmol})$ followed by $\operatorname{AgOTf}(0.023 \mathrm{~g}, 0.09 \mathrm{mmol})$. The precipitate was filtered off using a celite-plugged pipette. After $30 \mathrm{~min}$ the reaction vessel was taken out from a box. To the resulting metal catalyst was added 1,7-octadiene $(0.200 \mathrm{~g}, 1.81$ mmol) in $\mathrm{CH}_{2} \mathrm{Cl}_{2}$ dropwise at ambient temperature. After the resulting mixture was stirred at ambient temperature for $2 \mathrm{~h}$, most of the volatile materials were evaporated, and the crude product was analyzed by NMR and GC. Total absence of the starting olefinic peaks in the ${ }^{1} \mathrm{H}$ NMR due to the starting methylene compound ( $\delta 5.70-5.90 \mathrm{~m} ; 4.90-5.05 \mathrm{~m})$, and appearance of new olefinic $\mathrm{H}$ at $\delta 5.25-5.40(4 \mathrm{H})$ and vinyl- $\mathrm{CH}_{3}$ signals at $1.50-1.51(6 \mathrm{H})$ indicate isomerization of the double bonds without cyclization. Since the product is volatile the conversion was estimated to be $>95 \%$ by both NMR and GC. No further analysis was carried out.

\section{Synthesis of 6-tert-butyldimethylsiloxy)hex-1-ene (13)}

To a solution of $0.581 \mathrm{~g}(5.81 \mathrm{mmol})$ of 5- hexene-1-ol in $5 \mathrm{~mL}$ of DMF at $0{ }^{\circ} \mathrm{C}$ under nitrogen was added $1.19 \mathrm{~g}(17.4 \mathrm{mmol})$ of imidazole and $1.31 \mathrm{~g}(8.72 \mathrm{mmol})$ of $t$-butyldimethylsilyl chloride. The mixture was stirred at $\mathrm{rt}$ for 2 days and subsequently quenched with $10 \mathrm{~mL}$ of water. The aqueous layer was extracted with ether $(3 \times 10 \mathrm{~mL})$. The combined organic layers were washed with $2 \mathrm{~N}$ aqueous $\mathrm{NaOH}$ solution then brine, and dried over $\mathrm{MgSO}_{4}$ before concentration in vacuo. The residue was purified by flash chromatography on silica gel, eluting with hexane/ethyl acetate (98:2), to afford the silyl ether $(\mathbf{1 3})$ as a clear oil $(1.19 \mathrm{~g}, 96 \%)$. ${ }^{1} \mathrm{H}$ NMR ( $\left.\mathrm{CDCl}_{3}\right): \delta 5.73-5.90(\mathrm{~m}, 1 \mathrm{H}), 4.91-5.06(\mathrm{~m}, 2 \mathrm{H}), 3.62(\mathrm{t}, J=6.4 \mathrm{~Hz}, 2 \mathrm{H}), 2.03-2.12$ (m, $2 \mathrm{H}), 1.38-1.60(\mathrm{~m}, 4 \mathrm{H}), 0.90(\mathrm{~s}, 9 \mathrm{H}), 0.05(\mathrm{~s}, 6 \mathrm{H})$.

\section{Isomerization of 6-tert-butyldimethylsiloxy)hex-1-ene. General procedure A (Table 3, entry} 1)

To a solution of [(allyl) NiBr $]_{2}(5.2 \mathrm{mg}, 0.14 \mathrm{mmol})$ in $1 \mathrm{~mL}$ of $\mathrm{CH}_{2} \mathrm{Cl}_{2}$ under nitrogen at room temperature was added a solution of $\mathrm{Ph}_{3} \mathrm{P}(7.6 \mathrm{mg}, 0.28 \mathrm{mmol})$ in $1 \mathrm{~mL}$ of $\mathrm{CH}_{2} \mathrm{Cl}_{2}$. The resulting brown solution was added to a mixture of AgOTf $(10.3 \mathrm{mg}, 0.40 \mathrm{mmol})$ in $1 \mathrm{~mL}$ of $\mathrm{CH}_{2} \mathrm{Cl}_{2}$. After stirring for $1.5 \mathrm{~h}$ at rt, the mixture was filtered through a small plug of celite, and the precipitate was rinsed with $2 \mathrm{~mL}$ of $\mathrm{CH}_{2} \mathrm{Cl}_{2}$. The filtrate was collected in a Schlenk flask, and was taken out of the drybox. The catalyst solution was cooled to $-55^{\circ} \mathrm{C}$. Under an atmosphere of ethylene, $0.428 \mathrm{~g}(2.00 \mathrm{mmol})$ of alkene 13 was added dropwise to the catalyst solution. After stirring at $-55^{\circ} \mathrm{C}$ for $4 \mathrm{~h}$, the mixture was quenched with saturated $\mathrm{NH}_{4} \mathrm{Cl}$ solution and extracted $\mathrm{CH}_{2} \mathrm{Cl}_{2}(3 \times 10 \mathrm{~mL})$. The combined organic layers were dried over $\mathrm{MgSO}_{4}$ and concentrated in vacuo. The crude product was analyzed by GC, which indicated that the alkene had completely isomerized to two new products in a ratio of 3.5:1.0. The volatile crude product ( $>95 \%$ estimated by GC) was purified by chromatography on silica, eluting 
with ethyl acetate/hexane (98:2), to afford the product(s) $\mathbf{1 8}$ which was analyzed by GC and NMR. ${ }^{1} \mathrm{H}$ NMR $\left(\mathrm{CDCl}_{3}\right): \delta 5.40-5.46(\mathrm{~m}, 2 \mathrm{H}), 3.57-3.65(\mathrm{~m}, 2 \mathrm{H}), 1.97-2.10(\mathrm{~m}, 2 \mathrm{H}), 1.54-$ $1.67(\mathrm{~m}, 5 \mathrm{H}), 0.90(\mathrm{~s}, 9 \mathrm{H}), 0.05(\mathrm{~s}, 6 \mathrm{H})$.

\section{Palladium-catalyzed isomerization of 6-tert-butyldimethylsiloxy)hex-1-ene. General procedure $D$ (Table 3 , entry 2 )}

The isomerization reaction was carried out using [(allyl) $\mathrm{PdCl}]_{2}(0.50 \mathrm{mmol}),(o$-tol $){ }_{3} \mathrm{P}(1 \mathrm{~mol}$ $\%)$ and $\operatorname{AgOTf}(1 \mathrm{~mol} \%)$ in $\mathrm{CD}_{2} \mathrm{Cl}_{2}$. The reaction was followed by ${ }^{1} \mathrm{H} \mathrm{NMR}$ spectroscopy, which indicated maximum conversion to the products at $24 \mathrm{~h}$. The products $(E)$ - and $(Z)-\mathbf{1 8}$ $(80 \%, 3.7: 1.0)$ were identified by comparison of gas chromatogram and spectral properties of the sample from the previous run. In addition to $10 \%$ starting material, 9\% of an unidentified product was also detected by gas chromatography (see GC traces).

\section{Synthesis of 1-(but-3-enyloxy)-4-methoxybenzene (14)}

To a stirred solution of 4-methoxyphenol (1 g, $8.06 \mathrm{mmol})$, 3-buten-1-ol (0.99 g, $10.48 \mathrm{mmol})$, and triphenylphosphine $(2.75 \mathrm{~g}, 10.48 \mathrm{mmol})$ in anhydrous THF $(20 \mathrm{~mL})$ was added diisopropylazodicarboxylate $(2.12 \mathrm{~g}, 10.48 \mathrm{mmol})$ slowly at $0{ }^{\circ} \mathrm{C}$. After the reaction was stirred overnight at $\mathrm{rt}$, the mixture was diluted with EtOAc $(20 \mathrm{~mL})$ and water $(20 \mathrm{~mL})$, and separated. The crude compound was extracted with EtOAc $(3 \times 20 \mathrm{~mL})$ and the combined organic layers were dried over $\mathrm{Na}_{2} \mathrm{SO}_{4}$. The resulting product was purified by chromatography to afford 1.5 $\mathrm{g}(93 \%)$ of 14. ${ }^{1} \mathrm{H}$ NMR $\left(\mathrm{CDCl}_{3}\right): \delta 6.87-6.81(\mathrm{~m}, 4 \mathrm{H}, \mathrm{Ar}), 5.94-5.86(\mathrm{~m}, 1 \mathrm{H}$,

$\left.\mathrm{ROCH}_{2} \mathrm{CH}_{2} \mathrm{CH}=\mathrm{CH}_{2}\right), 5.18-5.09\left(\mathrm{q}, 2 \mathrm{H}, \mathrm{ROCH}_{2} \mathrm{CH}_{2} \mathrm{CH}=\mathrm{CH}_{2}\right), 3.97-3.95(\mathrm{t}, J=7.0 \mathrm{~Hz}, 2 \mathrm{H}$, $\left.\mathrm{ROCH}_{2} \mathrm{CH}_{2} \mathrm{CH}=\mathrm{CH}_{2}\right), 2.53-2.49\left(\mathrm{~m}, 2 \mathrm{H}, \mathrm{ROCH}_{2} \mathrm{CH}_{2} \mathrm{CH}=\mathrm{CH}_{2}\right), 3.75\left(\mathrm{~s}, 3 \mathrm{H}, \mathrm{ArOCH}_{3}\right)$,

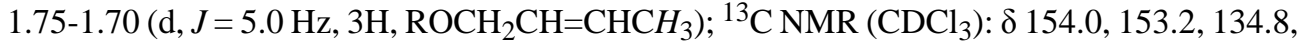
$117.1,115.8,114.8,68.1,55.9,33.9$.

\section{Isomerization of 1-(but-3-enyloxy)-4-methoxybenzene (14). General procedure D (Table 3, entry 3)}

1-(But-3-enyloxy)-4-methoxybenzene (30 $\mathrm{mg}, 0.168 \mathrm{mmol})$ was reacted with [(allyl)PdCl $]_{2}$ (1.6 mg, $0.0042 \mathrm{mmol}),(o-\mathrm{tol})_{3} \mathrm{P}(2.6 \mathrm{mg}, 0.0084 \mathrm{mmol}), \mathrm{AgOTf}(2.2 \mathrm{mg}, 0.0084 \mathrm{mmol})$, and $\mathrm{CH}_{2} \mathrm{Cl}_{2}$ at $\mathrm{rt}$ for $1 \mathrm{~d}$. The resulting product was purified by chromatography to afford $30 \mathrm{mg}$ (>99\%) of 19 as a mixture of $\mathrm{E}$ and $\mathrm{Z}$ isomers with the starting material. Based on ${ }^{1} \mathrm{H} N M R$ and GC, the conversion and $\mathrm{E} / \mathrm{Z}$ ratio were estimated as $96 \%$ and 5.9:1.0 respectively. ${ }^{1} \mathrm{H}$ $\operatorname{NMR}\left(\mathrm{CDCl}_{3}\right): \delta 6.86-6.80(\mathrm{~m}, 4 \mathrm{H}, \mathrm{Ar}), 5.84-5.80\left(\mathrm{~m}, 1 \mathrm{H}, \mathrm{ROCH}_{2} \mathrm{CH}=\mathrm{CHCH}_{3}, \mathrm{E}\right.$ and $\left.\mathrm{Z}\right)$, 5.74-5.68 (m, $1 \mathrm{H}, \mathrm{ROCH}_{2} \mathrm{CH}=\mathrm{CHCH}_{3}, \mathrm{E}$ and $\left.\mathrm{Z}\right), 4.54-4.53(\mathrm{~d}, J=5.5 \mathrm{~Hz}, 2 \mathrm{H}$, $\left.\mathrm{ROCH}_{2} \mathrm{CH}=\mathrm{CHCH}_{3}, \mathrm{Z}\right), 4.53-4.39\left(\mathrm{~m}, 2 \mathrm{H}, \mathrm{ROCH}_{2} \mathrm{CH}=\mathrm{CHCH}_{3}, \mathrm{E}\right), 3.75\left(\mathrm{~s}, 3 \mathrm{H}, \mathrm{ArOCH}_{3}\right)$, $1.75-1.70\left(\mathrm{~d}, J=5.0 \mathrm{~Hz}, 3 \mathrm{H}, \mathrm{ROCH}_{2} \mathrm{CH}=\mathrm{CHCH}_{3}\right),{ }^{13} \mathrm{C} \mathrm{NMR} \delta\left(\mathrm{CDCl}_{3}, \mathrm{E}\right.$ only $): 154.2,153.3$, 130.3, 126.8, 116.0, 69.7, 56.0, 17.9, 13.5.

The configuration of the major product was established by nOe studies. 

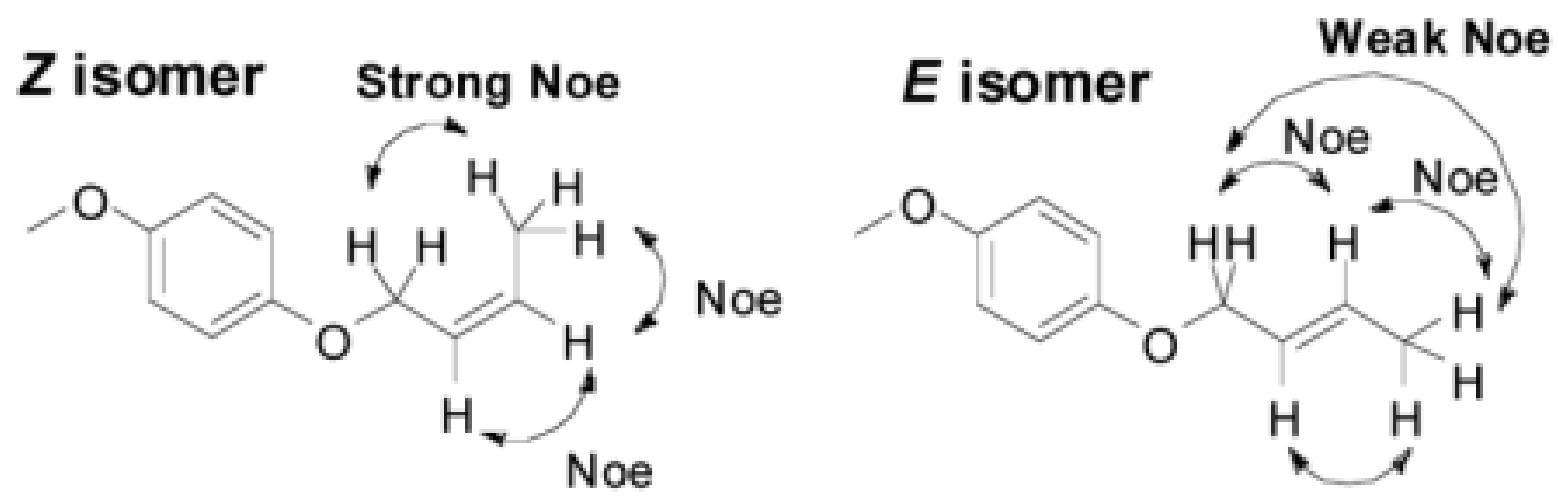

\title{
Isomerization of methyl 1-(2-butenyl)-2,5-cyclohexadiene-1-carboxylate (16). General procedure D (Table 3, entry 5 )
}

\begin{abstract}
Substrate $16(0.1 \mathrm{~g}, 0.5 \mathrm{mmol})$ was reacted with $5 \mathrm{~mol} \%$ [(allyl)PdCl $]_{2}(10.4 \mathrm{mg}, 0.026 \mathrm{mmol})$, $5 \mathrm{~mol} \%$ of $\left(o-\mathrm{CH}_{3}-\mathrm{C}_{6} \mathrm{H}_{4}\right){ }_{3} \mathrm{P}(16 \mathrm{mg}, 0.05 \mathrm{mmol}), \operatorname{AgOTf}(13 \mathrm{mg}, 0.05 \mathrm{mmol})$, and $\mathrm{CH}_{2} \mathrm{Cl}_{2}$ at $\mathrm{rt}$ for $1 \mathrm{~d}$. The resulting product was purified by chromatography to yield $91 \mathrm{mg}(91 \%)$ of $\mathbf{2 1}$ as a mixture $\mathrm{E} / \mathrm{Z}$ isomers. Based on the ${ }^{1} \mathrm{H} N M R$, the $\mathrm{E} / \mathrm{Z}$ ratio was estimated as 3.6:1.0. ${ }^{1} \mathrm{H}$ NMR $\left(\mathrm{CDCl}_{3}\right): \delta 5.88-5.73\left(\mathrm{~m}, 4 \mathrm{H},-\mathrm{CH}=\mathrm{CH}\right.$ - in the ring), 5.41-5.22 (m, $2 \mathrm{H}, \mathrm{CH}_{2}-\mathrm{CH}=\mathrm{CH}-$ $\mathrm{CH}_{2^{-}}, \mathrm{E}$ and $\left.\mathrm{Z}\right), 3.69$ (s, $\left.3 \mathrm{H}, \mathrm{OCH}_{3}, \mathrm{Z}\right), 3.67\left(\mathrm{~s}, 3 \mathrm{H}, \mathrm{OCH}_{3}, \mathrm{E}\right), 2.63\left(\mathrm{~m}, 2 \mathrm{H}, \mathrm{R}=\mathrm{CH}-\mathrm{CH}_{2^{-}}\right.$ $\mathrm{CH}=\mathrm{R}, \mathrm{E}$ and $\mathrm{Z}), 2.43\left(\mathrm{~d}, \mathrm{~J}=5.2 \mathrm{~Hz}, 2 \mathrm{H}, \mathrm{C}-\mathrm{CH}_{2}-\mathrm{CH}=\mathrm{CHCH}_{3}\right), 2.34(\mathrm{~d}, \mathrm{~J}=6.1 \mathrm{~Hz}, 2 \mathrm{H}, \mathrm{C}-$ $\left.\mathrm{CH}_{2}-\mathrm{CH}=\mathrm{CHCH}_{3}\right),[\delta 2.43+\delta 2.34] 2 \mathrm{H}, 1.51-1.61$ two sets of doublets $(\mathrm{d}, J=6.7 \mathrm{~Hz}, 3 \mathrm{H}$, $\left.\mathrm{C}=\mathrm{C}-\mathrm{CH}_{3}\right) ;{ }^{13} \mathrm{C} \mathrm{NMR}\left(\mathrm{CDCl}_{3}\right): \delta 174.7,128.6,127.0,126.7,125.4,125.3,51.9,47.9,43.4$, 37.2, 26.0, 17.9; HRMS $192.1132\left(\mathrm{M}^{+\bullet}\right.$; calcd for $\mathrm{C}_{12} \mathrm{H}_{16} \mathrm{O}_{2}$ 192.1150).
\end{abstract}

\section{Isomerization of (tert-butyI[[2,2-dimethyl-1-(1-propynyl)-3-pentenyl]oxy] dimethylsilane (17). General procedure D (Table 3, entry 6 )}

Substrate $17_{16}(0.1 \mathrm{~g}, 0.8 \mathrm{mmol})$ was reacted with $5 \mathrm{~mol} \%$ of $[(\text { allyl }) \mathrm{PdCl}]_{2}, 10 \mathrm{~mol} \%$ of (2$\left.\mathrm{Me}-\mathrm{C}_{6} \mathrm{H}_{4}\right)_{3} \mathrm{P}$ and $10 \mathrm{~mol} \% \mathrm{AgOTf}$ in $\mathrm{CH}_{2} \mathrm{Cl}_{2}$ at for $16 \mathrm{~h}$. The reaction mixture was quenched with saturated ammonium chloride and the product was extracted with ether. The dried organic layer concentrated and the product was purified by flash column chromatography to get $95 \mathrm{mg}$ $(95 \%)$ of 22 as a thick oil. Based on the ${ }^{1} \mathrm{H}$ NMR, the E/Z ratio was estimated as 8.0:1.0. ${ }^{1} \mathrm{H}$ NMR $\left(\mathrm{CDCl}_{3}\right): \delta 5.57-5.30(\mathrm{~m}, 2 \mathrm{H}), 4.00(\mathrm{~m}), 3.91(\mathrm{q}, J=2.3 \mathrm{~Hz})$ [together $1 \mathrm{H}, \mathrm{R} 3 \mathrm{Si}-\mathrm{O}-$ $\mathrm{CH}, 1.79\left(\mathrm{~d}, J=2.3 \mathrm{~Hz}, 3 \mathrm{H}, \mathrm{R}-\mathrm{C} \alpha \mathrm{C}-\mathrm{CH}_{3}\right), 1.66\left(\mathrm{~d}, J=5.6 \mathrm{~Hz}, 3 \mathrm{H}, \mathrm{CH}=\mathrm{CH}-\mathrm{CH}_{3}\right), 1.00$ ( $2 \mathrm{~s}$, separated by $\left.\sim 2 \mathrm{~Hz}, 6 \mathrm{H}, \mathrm{R}\left(\mathrm{CH}_{3}\right)_{2}\right), 0.10$ (2s, 9H, tBu in OTBS), 0.11 (s, 3H, Me in OTBS), 0.05 (s, 3H, Me in OTBS); ${ }^{13} \mathrm{C}$ NMR $\left(\mathrm{CDCl}_{3}\right): \delta 137.8,120.1,79.8,79.3,70.5,40.9,25.5$, 25.4, 22.5, 22.1, 18.0, 2.9, -4.5; HRMS 266.2057 ( $\mathrm{M}^{+*}$; calcd for $\left.\mathrm{C}_{16} \mathrm{H}_{30} \mathrm{O}_{4} \mathrm{Si} 266.2066\right)$.

Isomerization of 6-tert-butyldimethylsiloxy)hex-1-ene (13) using Grubbs second-generation catalyst. ${ }^{8 a}$

Using the same procedure and catalyst (10 mol\%) aforementioned, the isomerization of TBSprotected olefin $13(11.2 \mathrm{mg}, 0.052 \mathrm{mmol})$ was checked. The crude product was analyzed by GC. See Supporting Information for chromatograms.

\section{Isomerization of 1-(but-3-enyloxy)-4-methoxybenzene (14) using Grubbs second-generation catalyst shown in eq $1 .^{8 a}$}

The starting olefin 14 (9.3 mg, $0.052 \mathrm{mmol})$ in anhydrous $\mathrm{MeOH}(0.8 \mathrm{~mL})$ was treated with Grubbs second-generation catalyst $(4.4 \mathrm{mg}, 10 \mathrm{~mol} \%)$. The resulting solution was stirred at 60 
${ }^{\circ} \mathrm{C}$ for $12 \mathrm{~h}$. After the solvent was evaporated in vacuo, the residue was filtered on a silica pad and eluting with ether. The crude product was directly analyzed by GC. Supporting Information for chromatograms.

\section{Isomerization of 1-methylene-2,3,4-trihydronaphthalene (1) using Grubbs second- generation catalyst}

Using the same procedure and catalyst $(10 \mathrm{~mol} \%)$ aforementioned, the isomerization of olefin $\mathbf{1}(15.0 \mathrm{mg}, 0.104 \mathrm{mmol})$ was checked. The crude product was purified by short column chromatography, and analyzed by ${ }^{1} \mathrm{H}$ NMR.

\section{Isomerization of 2-(3-(3-(benzyloxy)phenyl)but-3-enyl)isoindoline-1,3-dione (3a) using Grubbs second-generation catalyst}

Using the same procedure and catalyst $(10 \mathrm{~mol} \%)$ aforementioned, the isomerization of olefin 3a $(10.0 \mathrm{mg}, 0.0261 \mathrm{mmol})$ was checked. The crude product was purified by short column chromatography, and analyzed by ${ }^{1} \mathrm{H}$ NMR.

\section{Isomerization of 6-tert-butyldimethylsiloxy)hex-1-ene (13) using $\left[\operatorname{Ir}(\mathrm{COE})_{2} \mathrm{Cl}_{2} / \mathrm{PCy}_{3} / \mathrm{NaBPh}_{4}\right.$ in $\mathrm{CH}_{2} \mathrm{Cl}_{2} /$ Acetone (Scheme 2). ${ }^{4 b, 6 \mathrm{~d}}$}

Using the same procedure and catalyst $(2 \mathrm{~mol} \%$ ) aforementioned, the isomerization of TBSprotected olefin 13 ( $25.5 \mathrm{mg}, 0.119 \mathrm{mmol})$ was checked. After the resulting mixture was stirred at $\mathrm{rt}$ for $3 \mathrm{~h}$, most of the volatile materials were evaporated, and the crude product was purified by column chromatography to get the isomerized silylenolether tert-butyl(hex-1-enyloxy) dimethylsilane $(24.0 \mathrm{mg}, 94 \%)$. The product was analyzed by ${ }^{1} \mathrm{H}$ NMR and GC. ${ }^{1} \mathrm{H}$ NMR $\left(\mathrm{CDCl}_{3}\right): \delta 6.21-6.18(\mathrm{dt}, 1 \mathrm{H}, \mathrm{J}=12.0,1.5 \mathrm{~Hz}, \mathrm{nBuCH}=\mathrm{CHOTBS}), 4.97-4.95(\mathrm{q}, 1 \mathrm{H}, 3.8 \mathrm{~Hz}$, $\mathrm{nBuCH}=$ CHOTBS $), 1.89-1.82(\mathrm{~m}, 2 \mathrm{H}, \mathrm{nBu}), 1.30-1.26(\mathrm{~m}, 4 \mathrm{H}, \mathrm{nBu}), 0.90-0.84(\mathrm{~m}, 12 \mathrm{H}$, tBuSi \& nBu), 0.10 (s, 6H, $\left.\mathrm{SiMe}_{2}\right)$.

\section{Isomerization of 1-(but-3-enyloxy)-4-methoxybenzene (14) using $\left[\operatorname{lr}(\mathrm{COE})_{2} \mathrm{Cl}_{2} / \mathrm{PCy}_{3} /\right.$ $\mathrm{NaBPh}_{4}$ in $\mathrm{CH}_{2} \mathrm{Cl}_{2} /$ Acetone. ${ }^{4 b, 6 \mathrm{~d}}$}

In a nitrogen filled drybox, a dry flask was charged with $[\mathrm{Ir}(\mathrm{COE}) \mathrm{Cl}]_{2}(1.1 \mathrm{mg}, 0.0012 \mathrm{mmol})$, $\mathrm{PCy}_{3}(1.9 \mathrm{mg}, 0.0068 \mathrm{mmol})$, and $\mathrm{NaBPh}_{4}(0.8 \mathrm{mg}, 0.0029 \mathrm{mmol})$, and the mixture was dissolved in $\mathrm{CH}_{2} \mathrm{Cl}_{2}$ /acetone $(0.52 \mathrm{~mL}, 25 / 1)$. After 5 min stirring, the starting olefin 14 (21.2 $\mathrm{mg}, 0.119 \mathrm{mmol})$ in $\mathrm{CH}_{2} \mathrm{Cl}_{2}(0.5 \mathrm{~mL})$ was added dropwise at rt. After the resulting mixture was stirred for $3 \mathrm{~h}$ at $\mathrm{rt}$, most of the volatile materials were evaporated, and the crude product was purified by column chromatography to yield the mixture of the desired product (19) and further isomerized 1-(but-1- enyloxy)-4-methoxybenzene (2-OPMP) (20.4 mg (96\%), 19:2OPMP $=1.0: 3.5$ (based on ${ }^{1} \mathrm{H}$ NMR)). The product was analyzed by ${ }^{1} \mathrm{H}$ NMR and GC. ${ }^{1} \mathrm{H}$ NMR $\left(\mathrm{CDCl}_{3}\right): \delta 6.92-6.88(\mathrm{~m}, 2 \mathrm{H}, \mathrm{Ar}), 6.84-6.79(\mathrm{~m}, 2 \mathrm{H}, \mathrm{Ar}), 6.36-6.33(\mathrm{dt}, 1 \mathrm{H}, \mathrm{J}=12.0$, $1.5 \mathrm{~Hz}, \mathrm{ROCH}=\mathrm{CHEt}$ ), 5.32-5.27 (m, 1H, ROCH=CHEt), 3.75 (s, 3H, OMe), 2.05-1.99 (m, $\left.2 \mathrm{H}, \mathrm{RCH}_{2} \mathrm{CH}_{3}\right), 1.05-0.98\left(\mathrm{t}, 3 \mathrm{H}, \mathrm{J}=6.0 \mathrm{~Hz}, \mathrm{RCH}_{2} \mathrm{CH}_{3}\right)$.

\section{Attempted isomerization of 1-methylene-2,3,4,5-trihydronaphthalene (1) using $\left.\operatorname{Ir}(\mathrm{COE})_{2} \mathrm{Cl}\right]_{2} /$ $\mathrm{PCy}_{3} / \mathrm{NaBPh}_{4}$ in $\mathrm{CH}_{2} \mathrm{Cl}_{2} /$ Acetone. ${ }^{4 b, 6 \mathrm{~d}}$}

Using the same procedure and catalyst $(2 \mathrm{~mol} \%)$ aforementioned, the isomerization of olefin $\mathbf{1}(17.1 \mathrm{mg}, 0.119 \mathrm{mmol})$ was checked. The crude product was purified by short column chromatography, and analyzed by ${ }^{1} \mathrm{H}$ NMR. 


\section{Attempted isomerization of 2-(3-(3-(benzyloxy)phenyl)but-3-enyl)isoindoline-1,3-dione (3a)} using $\left.\operatorname{Ir}(\mathrm{COE})_{2} \mathrm{Cl}\right]_{2} / \mathrm{PCy}_{3} / \mathrm{NaBPh}_{4}$ in $\mathrm{CH}_{2} \mathrm{Cl}_{2} /$ Acetone. ${ }^{4 b, 6 \mathrm{~d}}$

Using the same procedure and catalyst ( $2 \mathrm{~mol} \%)$ aforementioned, the isomerization of olefin 3a (22.8 mg, $0.060 \mathrm{mmol})$ was checked. The crude product was purified by short column chromatography, and analyzed by ${ }^{1} \mathrm{H}$ NMR.

\section{Supplementary Material}

Refer to Web version on PubMed Central for supplementary material.

\section{Acknowledgments}

Financial assistance for this research by NSF (CHE- 0610349) and NIH (General Medical Sciences, R01 GM075107) is gratefully acknowledged. Craig Smith also thanks the ACS Organic Division for a graduate fellowship sponsored by The Schering Plough Corporation.

\section{REFERENCES AND FOOTNOTES}

1. (a)Frauenrath H. Kropf H, Schaumann E. Houben-Weyl, E15/1 ThiemeStuttgart1995:1.(b) For a recent review describing applications in synthesis which appeared after the initial submission of this manuscript, see: (c)Donohue TJ, O'Riordan TJC, Rosa CP. Angew Chem Int Ed 2009;48:1014.

2. Greene, TW.; Wuts, PGM. Protective Groups in Organic Synthesis. Vol. 2. Wiley; New York: 1991. Kocienski, PJ. Protecting Groups. Thieme Verlag; Stuttgart: 2000.

3. (a) Otsuka S, Tani K. Synthesis 1991:665. (b) Frauenrath H, Brethauer D, Reim S, Maurer M, Raabe G. Angew Chem Int Ed 2001;40:177.

4. (a)Reuter JM, Salomon RG. J Org Chem 1977;42:3360.(b)Nelson SG, Bungard CJ, Wang K. J Am Chem Soc 2003;125:13000. and references cited therein. [PubMed: 14570453](c)Stevens BD, Bungard CJ, Nelson SG. J Org Chem 2006;71:6397. [PubMed: 16901121](d)Ohmura T, Yamamoto Y, Miyaura N. Organometallics 1999;18:413.(e) A mineral acid-mediated isomerization of terminal methylene compounds is unlikely to be of broad value for reactions of sensitive substrates reported in this paper: (f)Buckle DR, Arch JRS, Edge C, Foster KA, Houge-Frydrych CSV, Pinto IL, Smith DG, Taylor JF, Taylor SG, Tedder JM, Webster RAB. J Med Chem 1991;34:919. [PubMed: 2002472]

5. Wille A, Tomm S, Frauenrath H. Synthesis 1998:305.and references cited therein

6. (a) Baudry D, Ephritikhine M, Felkin H. J Chem Soc, Chem Commun 1978:694. (b) Matsuda I, Kato T, Sato S, Izumi Y. Tetrahedron Lett 1986;27:5747. (c) Baxendale IR, Lee AL, Ley SV. J Chem Soc, Perkin Trans 1 2002:1850. (d) Shen X, Wasmuth AS, Zhao J, Zhu C, Nelson SG. J Am Chem Soc 2006;128:7438. [PubMed: 16756287] (e) Patnam R, Júarez-Ruiz JM, Roy R. Org Lett 2006;8:2691. [PubMed: 16774233]

7. (a)Harrod JF, Chalk AJ. J Am Chem Soc 1964;86:1776.(b)Davies NR. Aust J Chem 1964;17:212.(c) Gosser LW, Parshall GW. Tetrahedron Lett 1971:2555.(d)Lochow CF, Miller RG. J Org Chem 1976;41:3020.(e)Malanga C, Urso A, Lardicci L. Tetrahedron Lett 1995;36:1133.(f) For reports on the use of isomerization of C-allyl compounds in the context of complex molecule synthesis, see: via Rh-intermediates: (g)Warmerdam E, Tranoy I, Renoux B, Gesson JP. Tetrahedron Lett 1998;39:8077. (h)Nakamura H, Arata K, Wakamatsu T, Ban Y, Shibasaki M. Chem Pharm Bull 1990;38:2435.Pd: (i)Whang K, Cooke RJ, Okay G, Cha JK. J Am Chem Soc 1990;112:8985.Use of a ruthenium hydride: (j)Curran DP, Jacobs PB, Elliott RL, Kim BH. J Am Chem Soc 1987;109:5280.

8. (a)Hanessian S, Giroux S, Larsson A. Org Lett 2006;8:5481. [PubMed: 17107052](b)Dinger MB, Mol JC. Eur J Inorg Chem 2003:2827.See, also: (c)Arisawa M, Terada Y, Nakagawa M, Nishida A. Angew Chem Int Ed 2002;41:4732. and references cited therein.(d)Yue CJ, Liu Y, He R. J Mol Catal A: Chem 2006;259:17.(e)Böhrsch V, Blechert S. Chem Commun 2006:1968.(f)Wipf P, Spencer SR. J Am Chem Soc 2005;127:225. [PubMed: 15631472](g)Schmidt B. Eur J Org Chem 2004:1865.For a bifunctional $\mathrm{Ru}$-catalyst which brings about isomerization of double bonds over 30 positions, see: (h)Grotjahn DB, Larsen CR, Gustafson JL, Nair R, Sharma A. J Am Chem Soc 2007;129:9592. [PubMed: 17636924] See also: (i)Cadot C, Dalko PI, Cossy J. Tetrahedron Lett 2002;43:1839.(j)Alcaide B, Almendros P, 
Alonso JM, Aly MF. Org Lett 2001;3:3781. [PubMed: 11700137](k)Donohue TJ, Rosa CP. Org Lett 2007;9:5509. [PubMed: 18004864]

9. (a)Zhang A, RajanBabu TV. J Am Chem Soc 2006;128:5620. [PubMed: 16637613](b)Smith CR, RajanBabu TV. Org Lett 2008;10:1657. [PubMed: 18351772](c)Smith CR, Lim HJ, RajanBabu TV. Synthesis. 2009 (in press).For a recent reviews of hydrovinylation see: (d)Jolly PW, Wilke G. Cornils B, Herrmann WA. Hydrovinylation. Applied Homogeneous Catalysis with Organometallic Compounds VCHNew York1996;2:1024-1048.1048(e)RajanBabu TV. Chem Rev 2003;103:2845. [PubMed: 12914483](f)RajanBabu TV. Synlett 2009:853. [PubMed: 19606231]

10. (a)Radetich B, RajanBabu TV. J Am Chem Soc 1998;120:8007.For other related observations see: (b)Lloyd-Jones GC. Org Biomol Chem 2003:215. [PubMed: 12929414](c)Kisanga P, Widenhoefer RA. J Am Chem Soc 2000;122:10017.(d)Yamamoto Y, Ohkoshi N, Kameda M, Itoh K. J Org Chem 1999;64:2178.(e)Heumann A, Moukhliss M. Synlett 1998:1211.(f)Grigg R, Malone JF, Mitchell TRB, Ramasubbu A, Scott RM. J Chem Soc, Perkin Trans 1 1984:1745.(g)Behr A, Freudenberg U, Keim W. J Mol Catal 1986;35:9.(h)Bogdanovic B. Adv Organomet Chem 1979;17:105.

11. Importance of tri-substituted alkenes, (a)Chatterjee AK, Grubbs RH. Org Lett 1999;1:1751. [PubMed: 10836036]A recent report on E/Z isomerization of arylalkenes. see: (b)Yu J, Gaunt MJ, Spencer JB. J Org Chem 2002;67:4627. [PubMed: 12076172]

12. (a) Nomura N, Jin J, Park H, RajanBabu TV. J Am Chem Soc 1998;120:459. (b) RajanBabu TV, Nomura N, Jin J, Nandi M, Park H, Sun X. J Org Chem 2003;68:8431. [PubMed: 14575468]

13. See Supporting Information for ${ }^{1} \mathrm{H}$ and ${ }^{13} \mathrm{C}$ NMR spectra of key starting materials and products, and gas chromatograms of products from various reactions.

14. Effect of counteranions in related reactions, see: Nandi M, Jin J, RajanBabu TV. J Am Chem Soc 1999;121:9899.

15. (a)Wilke G, Bogdonovic B, Hardt P, Heimbach P, Keim W, Kröner M, Oberkirck W, Tanaka K, Steinrücke E, Walter D, Zimmermann H. Angew Chem Int Ed Engl 1966;5:151.(b)Herrmann WA, Salzer A. Synthetic Methods of Organometallic and Inorganic Chemistry Georg Thieme VerlagStuttgart 1996;1:156. Details of the preparation of [(allyl)NiBr $]_{2}$ : (c)Smith CR, Zhang A, Mans D, RajanBabu TV. Org Synth 2008;85:248.

16. (a) Trost BM, Lautens M. J Am Chem Soc 1985;107:1781. (b) Trost BM. Acc Chem Res 1990;23:34.

17. DiRenzo, GM. For isolation of such an insertion product in styrene dimerization. Ph D Thesis.

University of North Carolina; 1997. Mechanistic Studies of Catalytic Olefin Dimerization Reactions Using Electrophilic $\eta^{3}$-allyl- Palladium(II) Complexes.

18. (a) Kobayashi H, Sonoda A, Iwamoto H, Yoshimura M. Chem Lett 1981;10:579. (b) Brookhart M, Grant B, Volpe AF Jr. Organometallics 1992;11:3920-3922.

20. Exon C, Magnus P. J Am Chem Soc 1983;105:2477. 


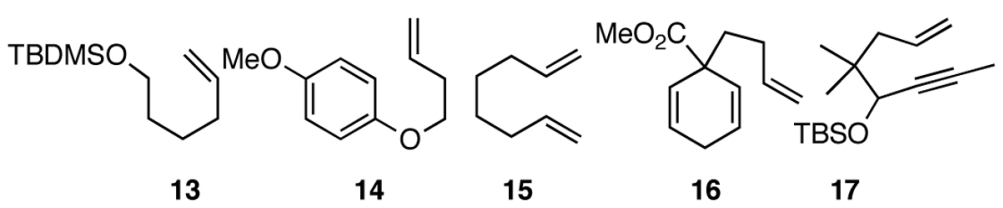

Figure 1.

Terminal alkene substrates for isomerization listed in Table 3 


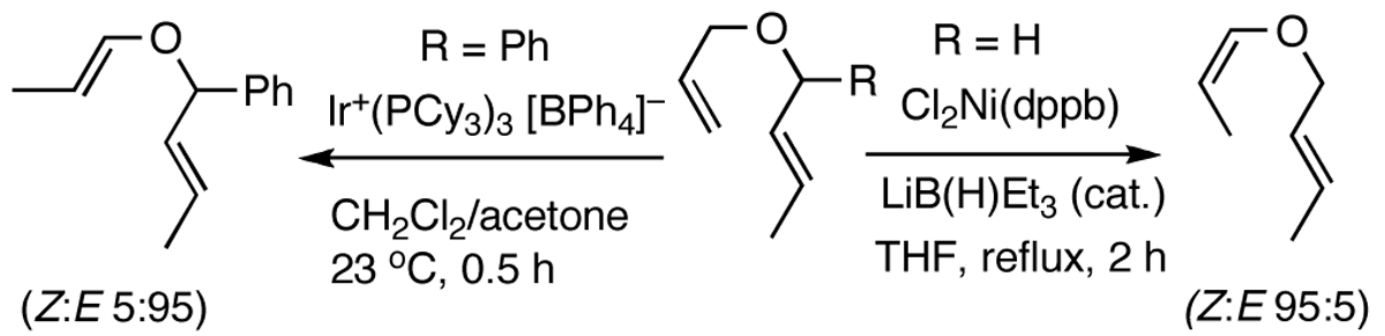

Scheme 1.

Isomerization of Allyl Ethers into Vinyl Ethers 


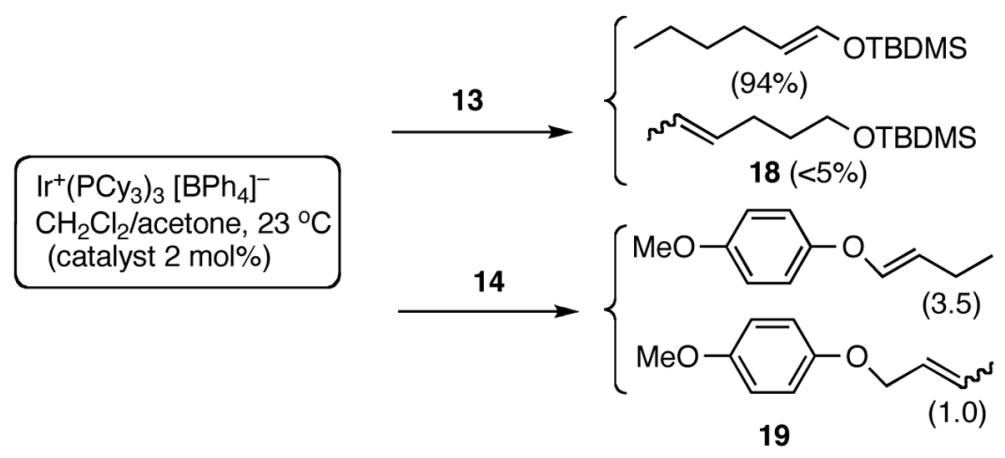

Scheme 2.

Isomerization of a Terminal Alkene using an Ir (I) Catalyst ${ }^{4 b}, 6 \mathrm{~d}$ 

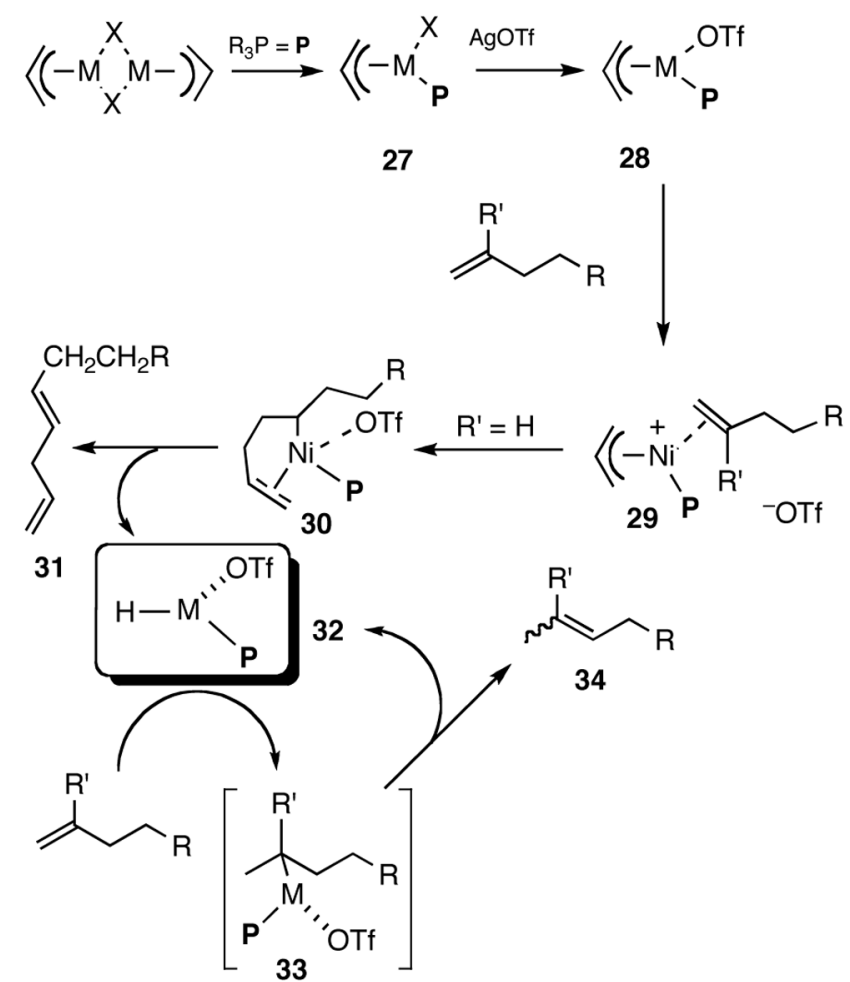

Scheme 3.

A Possible Mechanism for the Alkene Isomerization 
Table 1

Isomerization of 1-Methylenetetralin (1) and 1-(2-Phthalimidoethyl)styrene $\mathbf{3 a}{ }^{a}$

\begin{tabular}{|c|c|c|c|c|}
\hline \multirow{2}{*}{ entry } & \multirow{2}{*}{ catalyst (mol\%), additives (mol\%) } & \multirow{2}{*}{ conditions } & \multicolumn{2}{|c|}{ yield $(\%)$} \\
\hline & & & 2 & $4(E: Z)$ \\
\hline 1. & $\begin{array}{l}{[(\text { allyl }) \mathrm{NiBr}]_{2}(5), \mathrm{Ph}_{3} \mathrm{P}(10) \mathrm{AgOTf}(5),} \\
\text { ethylene }\end{array}$ & ethylene $(1 \mathrm{~atm}), 25^{\circ} \mathrm{C}, 2 \mathrm{~d}$ & 0 & $<5 \%$ \\
\hline 2. & $\begin{array}{l}{[(\text { allyl }) \mathrm{PdCl}]_{2}(5), \mathrm{Ph}_{3} \mathrm{P}(5) \operatorname{AgOTf}(5) \text {, }} \\
\text { ethylene }\end{array}$ & $\begin{array}{l}\text { ethylene ( } 1 \mathrm{~atm}, 20 \mathrm{~min}), 25^{\circ} \mathrm{C} \text {, } \\
2 \mathrm{~d}\end{array}$ & 90 & $79(15: 1)^{b}$ \\
\hline 3. & $\begin{array}{l}{[(\text { allyl }) \mathrm{PdCl}]_{2}(1), \mathrm{Ph}_{3} \mathrm{P}(5) \operatorname{AgOTf}(1)} \\
\text { diallyl ether }(1)\end{array}$ & $25^{\circ} \mathrm{C}, 1.5 \mathrm{~d}$ & 90 & $79(8: 1)^{b}$ \\
\hline 4. & $\begin{array}{l}{[(\text { allyl }) \mathrm{NiBr}]_{2}(1), \mathrm{Ph}_{3} \mathrm{P}(2) \mathrm{NaBARF}(1) \text {, }} \\
\text { diallyl ether (1) }\end{array}$ & $25^{\circ} \mathrm{C}, 2 \mathrm{~d}$ & 82 & -- \\
\hline 5. & $\begin{array}{l}{\left[(\text { allyl }) \mathrm{PdCl}_{2}(5),(o \text {-tol })_{3} \mathrm{P}(10) \mathrm{AgOTf}\right.} \\
(10), \mathrm{CH}_{2} \mathrm{Cl}_{2}\end{array}$ & $25^{\circ} \mathrm{C}, 2 \mathrm{~d}$ & $>99$ & $\sim 10^{c}$ \\
\hline $6^{d}$ & $\begin{array}{l}\left(\mathrm{Ir}(\mathrm{COE})_{2} \mathrm{Cl}\right]_{2}, \mathrm{PCy}_{3}, \mathrm{NaBPh}_{4}, \mathrm{CH}_{2} \mathrm{Cl}_{2} / \\
\text { acetone }(50: 1)\end{array}$ & $25^{\circ} \mathrm{C}, 3 \mathrm{~h}$ & $<2$ & $<2$ \\
\hline 7.e & {$\left[\mathrm{Cl}_{2} \mathrm{Ru} \mathbf{L}_{3}\right]$ Grubbs $2^{\text {nd }}$ Gen. (10)MeOH } & $60^{\circ} \mathrm{C}, 1 \mathrm{~d}$ & $\sim 7 \%$ & $\sim 7 \%$ \\
\hline
\end{tabular}

\footnotetext{
${ }^{a}$ See eq 5,6 and experimental section for details.

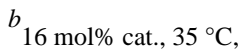

$c_{10 \mathrm{~mol} \% \text { cat. }}$

$d_{\text {ref. }} 6 \mathrm{~d}$, Scheme 1.

$e_{\text {ref. }}^{8 \mathrm{a}}$, see eq 1 .
} 
Table 2

Isomerization of 2,2'-Disubstituted Alkenes ${ }^{a}$

time (h)

1.<smiles>C=C1CCc2ccccc21</smiles>

5

2.<smiles>C=C(CC)c1ccc(Cl)cc1</smiles>

3.

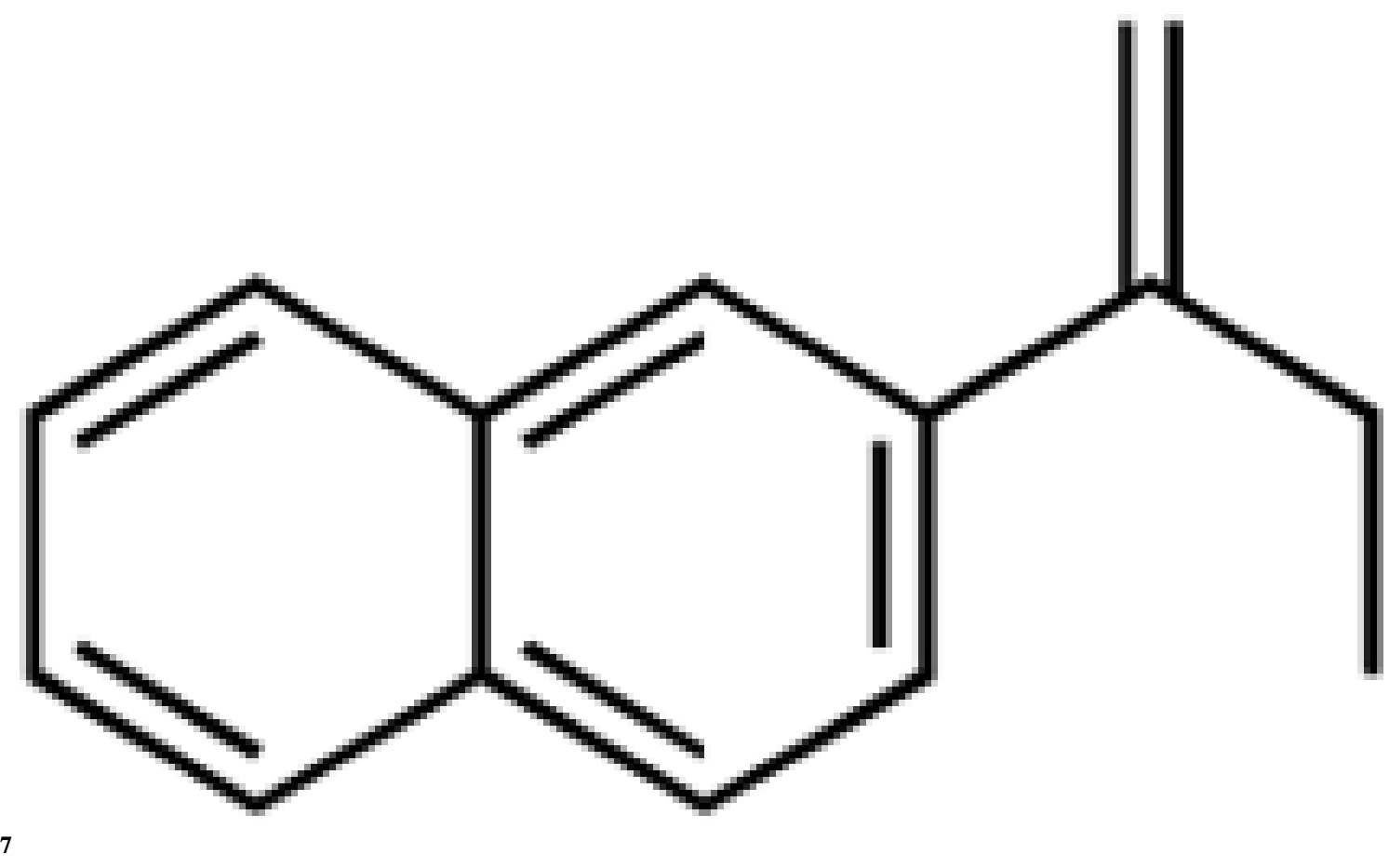


4.

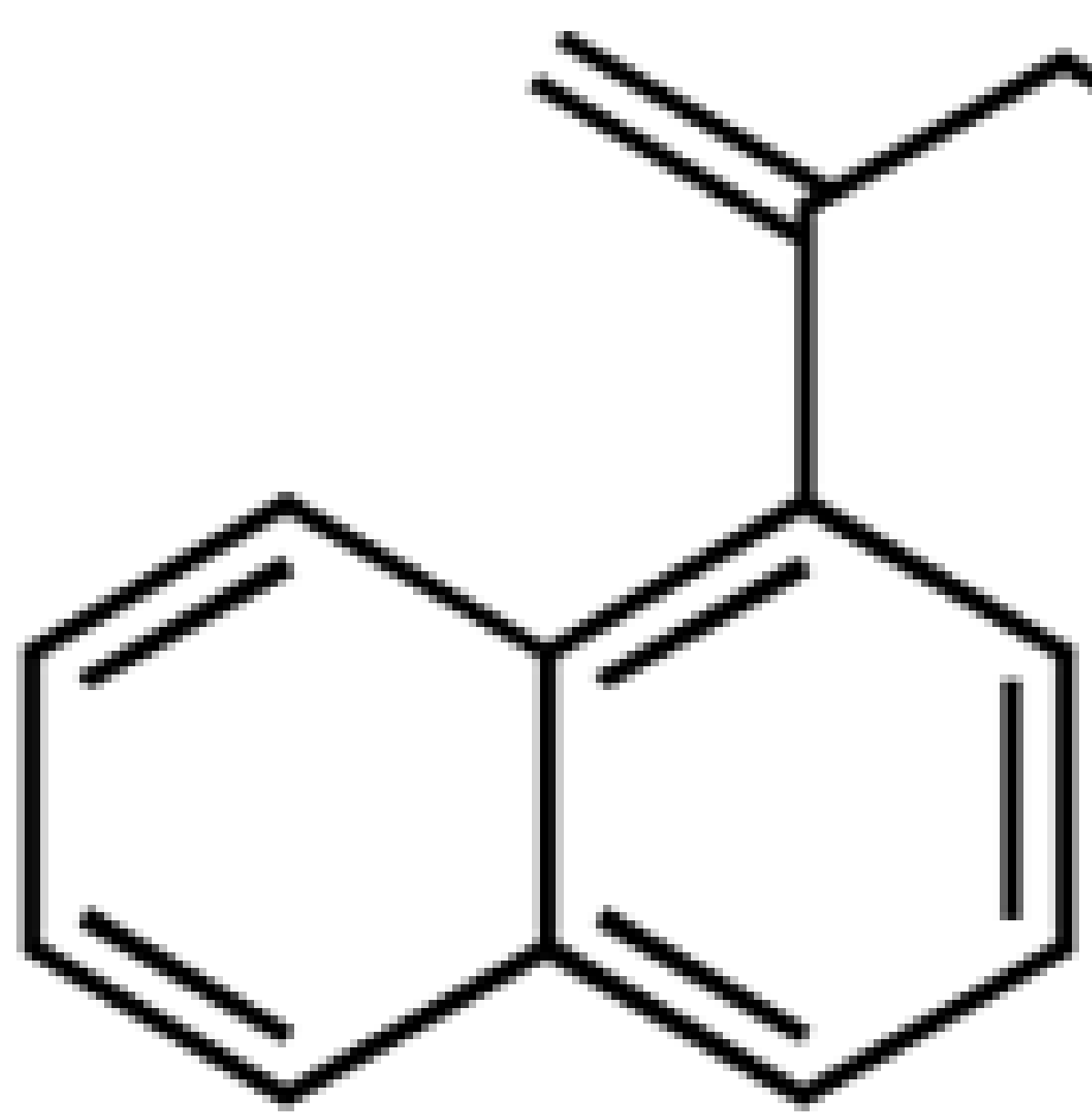

5.

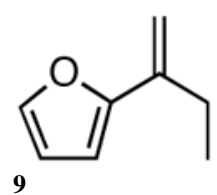




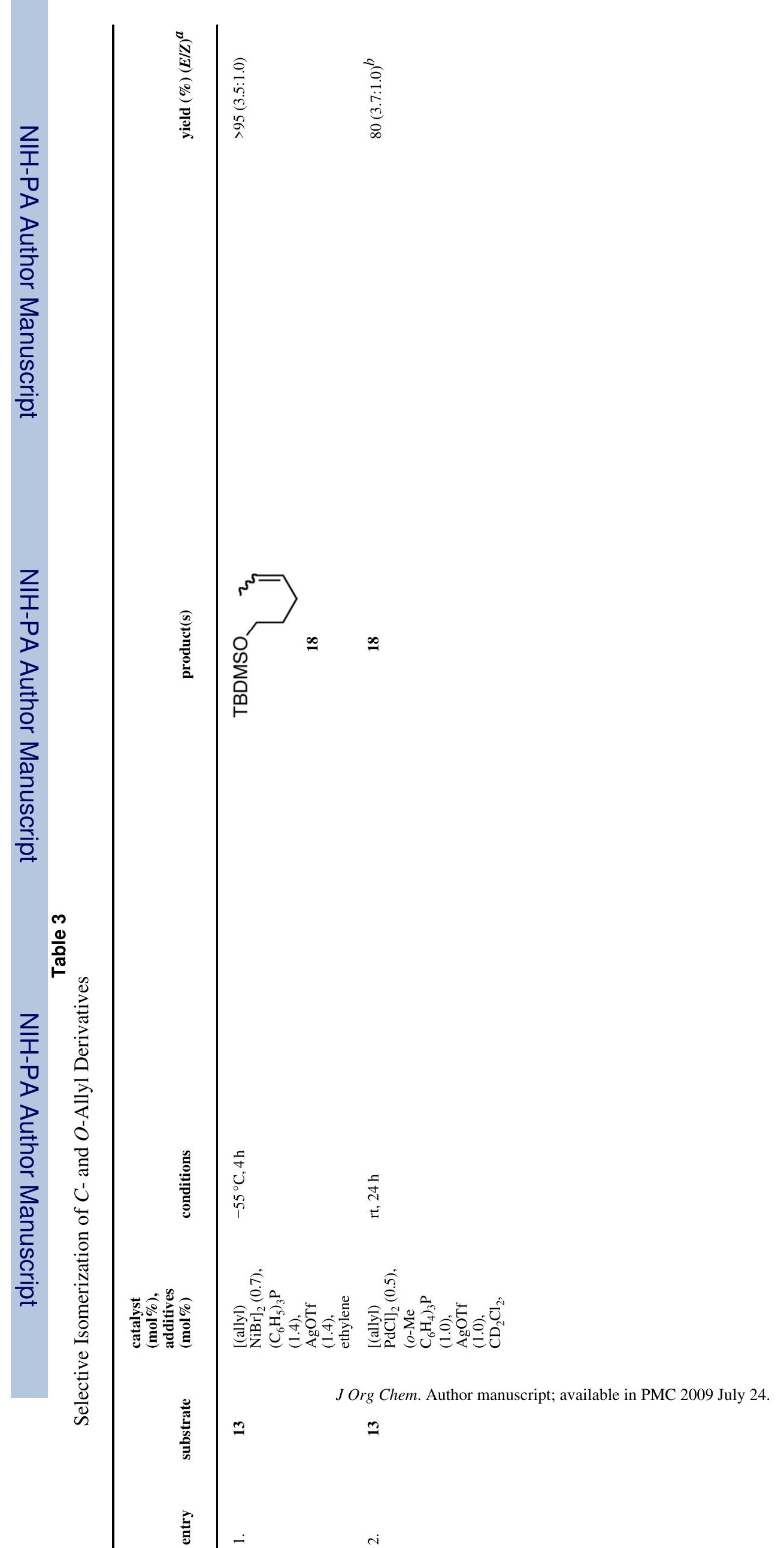




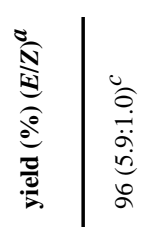
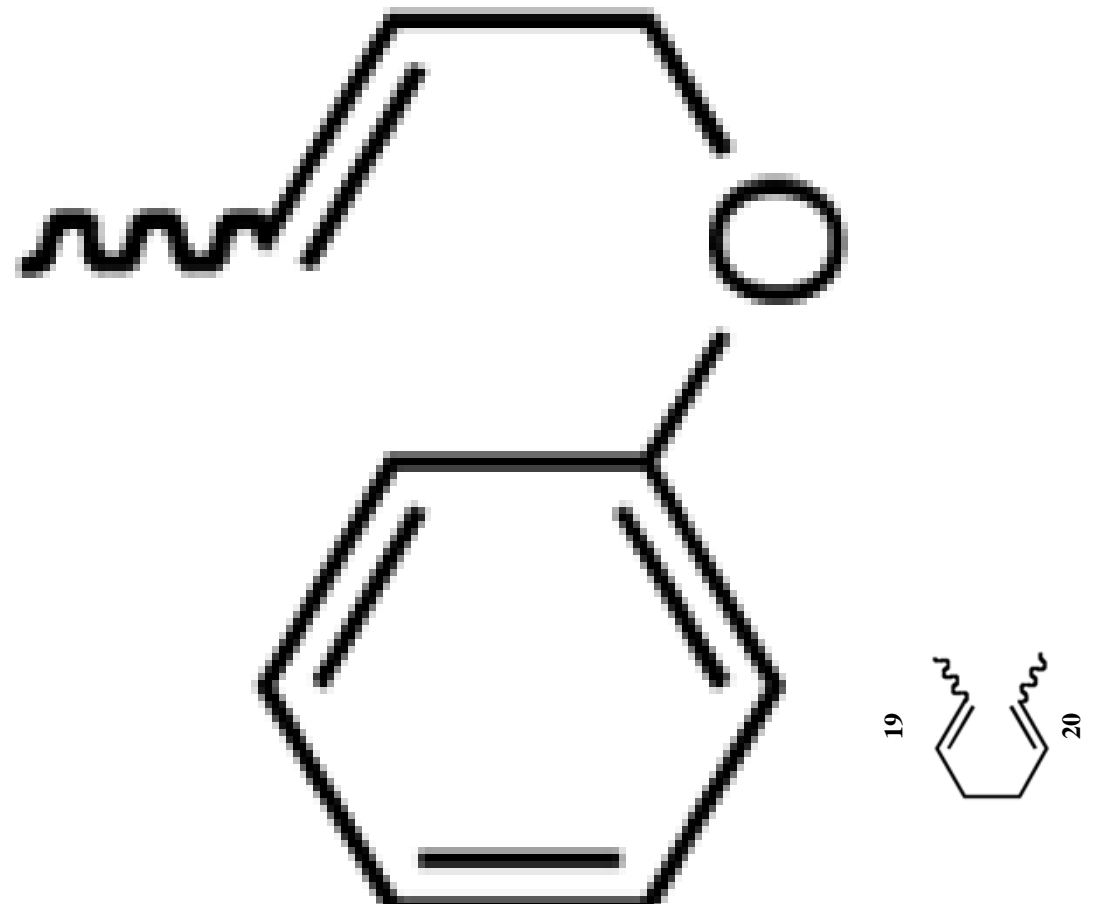

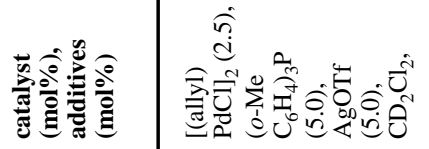

$\frac{2}{2}$

产

|ֶ

iี

๙ิ

तิ 0

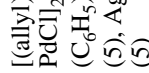

J Org Chem. Author manuscript; available in PMC 2009 July 24.

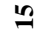




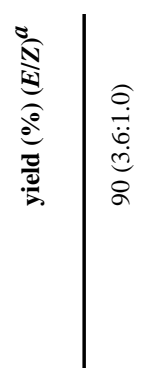
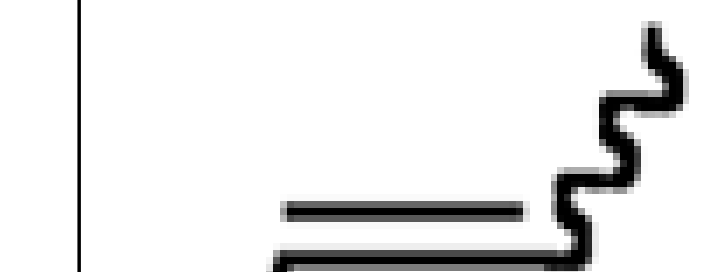